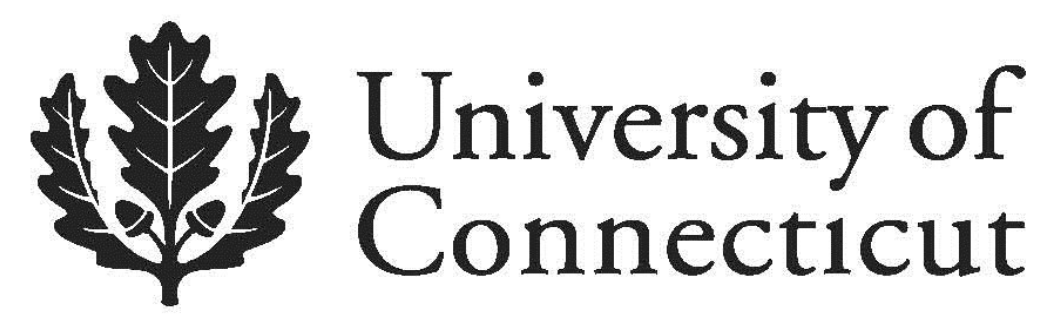

Department of Economics Working Paper Series

\title{
Do Constitutions Matter? The Effects of Constitutional Environmental Rights Provisions on Environmental Outcomes
}

Chris Jeffords

Indiana University of Pennsylvania

Lanse Minkler

University of Connecticut

Working Paper 2014-16

July 2014

365 Fairfield Way, Unit 1063

Storrs, CT 06269-1063

Phone: (860) 486-3022

Fax: (860) 486-4463

http://www.econ.uconn.edu/

This working paper is indexed on RePEc, http://repec.org 
Do Constitutions Matter? The Effects of Constitutional Environmental Rights Provisions on Environmental Outcomes

\author{
Chris Jeffords ${ }^{1}$ \\ Indiana University of Pennsylvania
}

Lanse Minkler

University of Connecticut

JEL Codes: K10, K32, O13, Q50, Q56

JEL Keywords: Constitutional Law, Environment, Environmental Kuznets Curve, Environmental Rights

\begin{abstract}
We use a novel data set within an instrumental variables framework to test whether the presence and legal strength of constitutional environmental rights are related to environmental outcomes. The outcome variables include Yale's Environmental Performance Index and some of its components. The analysis accounts for the possibility that a country which takes steps to protect the environment might also be more likely to constitutionalize environmental rights. Controls include: (1) gross domestic product per capita (2) whether the country is a party to the International Covenant on Economic, Social, and Cultural Rights; (3) rule of law; (4) population density; and (5) exogenous geographic effects. The inclusion of income means that our study is directly related to the Environmental Kuznets Curve literature. We find that constitutions do indeed matter for positive environmental outcomes, which suggests that we should not only pay attention to the incentives confronting polluters and resource users, but also to the incentives and constraints confronting those policymakers who initiate, monitor, and enforce environmental policies.
\end{abstract}

\footnotetext{
${ }^{1}$ Corresponding Author: jeffords@iup.edu. The authors thank seminar participants at the 2014 Association for Social Economics sub-meeting of the AEA/ASSA annual meeting and IO/Law/Environmental workshop participants at the University of Connecticut for helpful comments. We also thank Ling Huang, Jill McCluskey, Nishith Prakash, Kathleen Segerson, Alexi Thompson, and Brandon Vick for thoughtful discussions and suggestions that improved the paper. Of course all errors are our own.
} 


\section{Introduction}

To what extent, if any, are constitutional environmental rights (CER's) provisions necessary for good environmental outcomes? Clearly they are not sufficient for "good" environmental outcomes. Intelligent policy design, financial resources and supporting institutions, like quality legal and political systems, are also required to some degree. For myriad reasons, geography also matters. But the question of possible necessity becomes increasingly important as we search for solutions to regional problems like water scarcity and pollution, and universal issues like global warming. To our knowledge, with once recent exception, this topic has not been systematically studied before.

Constitutional provisions that create CER's could matter because rights-holders achieve an elevated status. Donnelly $(2003, \mathrm{p} .8)$ frames it this way:

To have a right to $\mathrm{x}$ is to be entitled to $\mathrm{x}$. It is owned to you, belongs to you in particular. And if $\mathrm{x}$ is threatened or denied, right-holders are authorized to make special claims that ordinarily "trump" utility, social policy, and other moral or political grounds for action. (Dworkin, 1977: xi 90).

In principle at least, CER's enable rights-holders to hold policymakers accountable if their entitlements are violated. The added degree of accountability is what gives rights their bite. CER's are meta-rights that may induce legislation and regulation, and/or provide rights-holders the ability to file lawsuits (Boyd, 2012). Policymakers may or may not prefer to put effort and resources into good environmental policy, but if environmental rights-holders exist and are able to press their demands, policymakers are ostensibly required to do so.

Rights come in many shapes and sizes, and human rights are special rights that everyone has just by virtue of our humanity. Yet we do not have human rights to all things that are good or desirable; instead human rights seek to ensure the minimal conditions necessary for a dignified life (Donnelly, 2003). Though human rights scholars have called for a class of "emergent rights" that includes general environmental rights (ER's), they have not yet achieved the status of legal human rights in the principal international human rights documents (though property rights have) (Hiskes, 2009). As a specific exception, in 2010 the human right to water and sanitation was legally established by the United Nations General Assembly. ${ }^{2}$

Yet we know that significant conventional human rights violations occur daily throughout the world. So those skeptical about the importance of CER's could first point to that simple fact. The argument could proceed by acknowledging that there are places that don't have CER's but do have a good environmental record. For instance, according to the Environmental Performance Index (EPI) created by the Yale Center for Environmental Law and Policy, the United Kingdom (UK) ranked nine while Iceland ranked 13 out of 132 countries in 2012. ${ }^{3}$ We will use this index and its components as our key dependent variables, however the point is that the UK does not even have a constitution, and Iceland does not have any CER's in

${ }^{2}$ http://www.un.org/waterforlifedecade/human right to water.shtml accessed December 19, 2013.

${ }^{3}$ http://epi.yale.edu/epi2012/rankings accessed December 19, 2013. The United States is a middling performer, ranked at 49 . The US constitution does not contain any CER's. 
its constitution. But they do have comparatively good environmental performance records, so, the argument goes, constitutions are not absolutely necessary. Critics could also argue that CER's are unenforceable, ineffective, harbingers of frivolous lawsuits, a form of cultural imperialism, and a threat to democracy because they shift power from elected legislators to judges (Boyd, 2012).

So the question needs to be resolved empirically. In order to test the hypothesis that CER's are to some extent necessary for good environmental outcomes, we construct new CER variables from the dataset compiled in Jeffords (2013). Constitutions from 198 countries were coded for CER's into seven different categories. Perhaps surprisingly, 125 countries have at least one CER. Those CER variables serve as the primary explanatory variables on the EPI and its components. To account for the idea that a country may be able to grow out of its environmental problems we include income as a central control, which means that our study relates directly to the Environmental Kuznets Curve (EKC) literature. Furthermore, we implement an instrumental variables (IV) framework to account for the possibility that a country which takes steps to protect the environment might also be more likely to constitutionalize ER's. Ultimately we find robust evidence that constitutions do indeed matter, which suggests that we should not only pay attention to the incentives confronting polluters and resource users, but also to the incentives and constraints confronting those policymakers who initiate, monitor, and enforce environmental policies.

\section{Literatures}

Our research question cuts across two distinct literatures, one in environmental economics and one in constitutional political economy. Consider each in turn.

\subsection{Environmental Kuznets Curve}

While environmental economists are perhaps most concerned with the effects of specific policy instruments on specific environmental outcomes, a sizable literature does investigate the effects of economy wide characteristics more generally. The literature on the EKC examines the extent to which environmental degradation is related to growth. An inverted U-shaped curve, with environmental degradation on the vertical axis and income on the horizontal axis, exists if at some point in a country's development environmental degradation decreases with additional income. The factors identified for that negative relationship include the (1) shift to service industries, (2) increased demand for environmental amenities, and (3) stringent regulation, all of which are associated with higher levels of economic development. ${ }^{4}$

The empirical literature on the EKC initially examined the effect of income on various water and air pollution measures in cross-country and panel studies. As Thompson (2012) notes, some studies find evidence for the EKC (but with vastly different turning points), while others do not. The more recent trend relevant for our study is the inclusion of additional explanatory variables, and in particular those that proxy for political institutions.

\footnotetext{
${ }^{4}$ See Thompson (2012) for a comprehensive review of the EKC literature.
} 
Bhattarai and Hammig (2001) aggregate the civil and political rights indices from Freedom House to create a political institutions explanatory variable. Freedom House analysts create the indices by subjectively evaluating criteria regarding issues like election fairness, the role of the opposition party, the freeness of the press, the independence of the judiciary, and the rule of law. The authors use this variable in their study on the associates of deforestation in Latin America, Africa and Asia. The idea is that good political institutions may weaken the income effect because of enhanced citizen participation and more secure property rights. Bhattarai and Hammig (2001) do find evidence for the existence of the EKC and also that improvements in political institutions do significantly reduce deforestation.

Both Chen (2010) and Castiglione, Infante, and Smirnova (2012) represent recent attempts to capture the effects of the rule of law into empirical EKC analyses. Both use the same rule of law variable from The World Bank's World Governance Indicators, as well as similar regression techniques and identification strategies. The subjective rule of law variable reflects views on the protection of property and human rights, the quality of contract enforcement and the judicial system, and trust in police and politicians. Chen (2010) finds that both income and the rule of law have positive effects on environmental policy stringency in 71 countries in the year 2000. Castiglione, Infante, and Smirnova (2012) find that the rule of law has differential effects on carbon emissions in 28 European countries, partly based on the country's sector composition, and whether or not it had a Socialist past.

Somewhat similar to the political institutions variable used by Bhattarai and Hammig (2001), the rule of law variable tries to capture the willingness of a country to establish good environmental policies and then advance and enforce those chosen. This literature is agnostic on the exact policies chosen. In contrast, most environmental economists working on policy want to know specifically the costs and benefits that various environmental instruments (e.g., emission taxes, subsidies, and tradable allowances, and performance standards and mandates) imply for specific environmental problems (Goulder and Parry, 2008). But policy efficacy requires more than just clever design, it also requires policymaker willingness. The question is if constitutionalization of ER's can "enhance" that willingness.

\subsection{Constitutions}

Most modern constitutions contain three main parts: a bill of rights, provisions on government structure and regulation, and procedures for amendment (Elster, 1995). Influential economists pioneered the notion that constitutions matter because they establish rules that constrain policymakers (Buchanan and Brennan, 1981; North and Weingast, 1989). Politicians are not just passive implementers of constituent interests; instead, just like everyone else, they have their own utility functions. So even if a politician really did prefer to dedicate time and scarce resources to environmental policymaking during an election, actual environmental constitutional rules would provide constraints on elected politicians should their preferences diverge over time.

In principle, statutory law could also establish these constraints (as well as positive directives) for policymakers. But the rights granted in statutory law only constrain policymakers as defined by the statute, and such rights can be altered or eliminated by even transitory majorities. In contrast, those constitutional rights that are legally enforceable are often broader 
and protected even from the majority by the judiciary and constitutional courts (Osiatynski, 2007). Because constitutions are difficult to change, they represent what is most enduringly important to a country.

Constitutional language does matter. A common distinction, especially when it comes to human rights, separates constitutional provisions into "directive principles" or enforceable law. Directive principles refer to aspirational policy goals, whereas enforceable law means legally binding. Nevertheless, even constitutional provisions regarded as directive principles can pose soft constraints on policymakers in the sense that breaching the underlying policy goals can reduce a policymaker's credibility and reduce reelection chances-or worse (Minkler, 2009). It turns out that most of the world's countries seem to view ER's as enduringly important. After examining 198 national constitutions, Jeffords (2013) finds 125 that contain at least one ER. That study provides the basis for our key constitutional law variable, with the number and strength of rights supplying additional variation.

While there has been a recent surge of work on the effects of institutions (generally) on economic outcomes, primarily economic growth, very little has been done on the effects of constitutional provisions on economic outcomes. ${ }^{5}$ The notable exception is Persson and Tabellini (2000). Those authors try to identify the major effects of two constitutionally mandated political institutions: presidential versus parliamentary governing systems, and majoritarian electoral rules versus proportional representation. They find that presidential and majoritarian systems have smaller governments (as measured by government spending divided by gross domestic product), majoritarian systems have smaller welfare state spending and budget deficits, and that parliamentarian government spending increases during downtimes and are not reversed during booms. ${ }^{6}$ At best this study only tangentially relates to environmental outcomes.

David Boyd's rich 2012 study is the most pertinent to our own. Boyd, an environmental lawyer, carefully examined all 92 countries where there is a CER to live in a healthy environment to see if the rights resulted in statutory legislation, environmental regulation, and/or lawsuits filed. As a summary of his qualitative analysis, Boyd (2012, pp. 251-252) finds (1) 78 out of 92 countries incorporated the CER into major legislation, (2) CER's have had a lesser, but growing, effect on the filing and adjudication of environmental lawsuits, (3) procedural ER's - the rights to information, participation, and access to justice-are important complements to the right to live in a healthy environment, and (4) the CER to live in a healthy environment has had a lot of the intended benefits with few of the drawbacks identified by the critics. Regionally, Boyd identifies certain Latin American countries, especially Argentina, Brazil, Columbia, and Costa Rica, where the CER has prompted both judicial and legislative approaches, and most of Western Europe as furthest along in CER induced change. ${ }^{7}$ There are

\footnotetext{
${ }^{5}$ This is especially curious if, following Douglas North, institutions are formal and informal constraints on behavior that facilitate purposeful action. Some well known examples in the institutions literature include Sokoloff and Engerman (2000), Acemoglu, Johnson, and Robinson (2001), and La Porta, Lopezde-Silanes, and Shleifer (2008). See Spolaore and Wacziarg (2013) for a recent review.

${ }^{6}$ See Acemoglu (2005) for a review of this book.

${ }^{7}$ Boyd (2012, pp. 129-131) identifies Argentina as a remarkable case where the CER to a healthy environment has permeated all environmental law and policy. Argentina's General Law on the
} 
instances in other regions as well, but Africa in particular suffers from the lack of effective legal institutions, a characteristic also shared by some Asian and Eastern European countries.

Boyd (2012, ch. 12 and appendix 1) also provides some statistical analysis. His main result uses ANOVA to compare the means of two groups of countries, those with no CER's $(n=34)$, and those with a CER $(n=116)$. These means are correlated with the associated means of "ecological footprints" for 2008. The ecological footprint comes from the Global Footprint Network and is an indicator that purports to measure how much of the regenerative capacity of a country is used by human activities. ${ }^{8}$ It includes "the area of land and water need to produce crops, livestock, fish, wood products, and energy, as well as the area needed to absorb the the carbon dioxide produced by burning fossil fuels" (Boyd 2012, p. 257). While perhaps a good index for sustainability, the ecological footprint has been criticized for its failure to include measures for things like environmental health, depletion of non-renewable materials, economic trade, effects on oceans, and that account for variability among nations (Boyd 2012, pp. 257258). Boyd does find a statistically significant difference between the group means, with the CER group enjoying a lower ecological footprint. ${ }^{9}$ While Boyd's quantitative exhibit is suggestive, our effort here uses economic analysis, more general indicators of environmental performance, and an objective, targeted CER variable in order to disentangle and identify the links between CER's and environmental performance.

\section{Variable Descriptions}

The following sections outline the variables used in the empirical analysis. ${ }^{10}$

\subsection{Dependent Variables}

EPI, and its two objective categories/components of Ecosystem Vitality (EV) and Environmental Health (EH), comprise our dependent variables. ${ }^{11} \mathrm{EPI}$ is an "outcome-oriented performance

Environment authorizes judges to take preventative action. And a globally important case arose in 2004 when citizens sued the national and provincial governments, the city of Buenos Aires, and forty four industrial facilities for polluting the Matanza-Riachuelo River, home of millions of people, many of whom are poor. In a series of decisions the Supreme Court required the government to first conduct and environmental assessment and initiate an environmental education program about wastewater, then to establish a comprehensive cleanup and restoration plan (reviewed by plaintiffs and experts), and, finally specific actions like: scheduled inspections and wastewater treatment plans-- with fines for violations; closure and cleanup of all illegal dumps; improvement of drinking-water, sewage treatment and stormwater discharge systems; and ongoing oversight by the federal Auditor General, committee of NGO's, and federal court.

${ }^{8}$ See Ewing, et al (2008).

${ }^{9}$ Boyd (2012) also provides similar analyses for much smaller samples (30 OECD countries, along with the richest country subsample) using data from researchers at Simon Frazer University over 29 indicators. Unfortunately that data is only available for OECD countries.

${ }^{10}$ Summary statistics for the dependent, control, and instrumental variables are listed in Table 2.

${ }^{11}$ In an effort to better link with the EKC literature, we also explored specifications using specific environmental outcome variables such as metric tons per capita carbon dioxide (CO2) emissions, per 
index" which "track[s] national environmental conditions on a quantitative basis by measuring proximity to policy targets using the best data available (Emerson et. al., 2012, Appendix II, pp. 1)." According to the EPI Summary for Policymakers produced by the Center for Environmental Law and Policy (Yale University) and the Center for International Earth Science Information Network (Columbia University), the 2012 EPI ranks 132 countries on 22 performance indicators across ten categories: child mortality; water (effects on human health); air pollution (effects on human health); water resources (ecosystem effects); biodiversity and habitat; forestry; fisheries; agriculture; and climate change. Each policy category of the index is used to track performance and progress on EV and EH.

The index is calculated by applying an aggregate $70 \%$ weight to the EV component and an aggregate $30 \%$ weight to the $\mathrm{EH}$ component. ${ }^{12}$ The EV component is comprised of 17 indicators including change in water quantity, forest loss, carbon dioxide emissions per capita, and the overexploitation of fish stocks, while the $\mathrm{EH}$ component is comprised of five indicators ranging from child mortality to indoor air pollution to access to sanitation and drinking water. Each indicator is vetted for relevance, performance orientation, established scientific methodology, data quality, time series availability, and completeness (Emerson et. al., 2012, pp. 14). EV and $\mathrm{EH}$ are then formed by considering target levels and weights for each indicator, where the levels and weights are subjected to sensitivity analysis. The indicators and the corresponding weights are illustrated in Figure 1 in the Appendix I.

\section{[Insert Figure 1 About Here]}

One particular advantage of the EPI is that it attempts to account for country heterogeneity. How can we compare the environmental performance of a landlocked desert country with that of an island nation? The EPI developers use the notion of "materiality," which means that if some indicator is not relevant, say fisheries for a landlocked country, "the indicator is 'averaged around,' meaning the other indicators in a particular category receive more weight" (2012 EPI Report, p. 23). While weighting, and differential weighting, of indicators entails some researcher subjectivity, it is unavoidable for any index that attempts to systematically compare heterogeneous countries.

We use the 2012 version of the EPI which reflects a new 70-30 weighting scheme on EV and $\mathrm{EH}$, and a reduction in performance indicators from 25 to $22 .{ }^{13} \mathrm{EPI}$ is interpreted in the

capita nitrous oxide emissions (measured in thousand metric tons of $\mathrm{CO} 2$ equivalent), and methane emissions (measured in kilotons of $\mathrm{CO} 2$ equivalent). The estimation results are available from the authors upon request.

${ }^{12}$ For a complete description of how the index is calculated see the full report of the $2012 \mathrm{EPI}$ available at http://epi.yale.edu. The "transformation needed for aggregation" section associated with each indicator in the 2012 EPI (as listed in Appendix 1 - Indicator Profiles - of the 2012 EPI report) notes that indicator benchmark targets are formed based on time series data from 2000-2010 for the underlying indicator. This is important because it informs the structural form of our empirical analysis outlined in Section 4.

${ }^{13}$ Although the EPI data and report are listed as 2012, the underlying data is from 2010 or earlier (as noted by the descriptions in Appendix 1 (Indicator Profiles) of the 2012 EPI Report). In fact, the historical EPI data file has identical values on a country-by-country basis for the 2010 and $2012 \mathrm{EPI}$, and the EV 
following way: the higher the index value between $0-100$, the greater the country's performance and progress on the EV and EH policy objectives categories. While the recently released $2014 \mathrm{EPI}$ is also available, because the calculation and components of EPI has changed multiple times even between the 2010, 2012, and 2014 releases, we use the 2012 data. Most importantly, the weights for each of the 2014 indicators are not transparent. .Nevertheless, we do re-estimate our regressions using the 2014 data and find that the results do substantially change (those results are reported in Appendix 4).

Why don't we employ specific environmental outcome variables as our primary dependent variables, similar to the EKC approaches discussed above? By its very nature constitutional language is general. It sets limits or establishes goals, with detailed implementation the responsibility of legislative and regulatory bodies. For example, laws addressing air and water pollution might be derived from a CER provision or, as is the case in the US, through separate means, but the CER provision language itself is not what would be used to actually specify the implementation details or policy to clean air and water. That subordinate task falls to statutory laws debated and agreed to by lawmakers who can consider each country's particular circumstances. The environmental issues (and geography, history, institutions and previous policy trajectory) confronting Chad and the Saint Vincent and the Grenadines are quite different, and so will be the appropriate policy levers. Therefore because we are examining the potential effects of CER provisions, which by their nature are general, we need a general outcome measure as well. Currently, the EPI is best suited for that purpose.

\subsection{Primary Independent Variables}

The primary independent variables of interest are (1) the presence of a CER, and (2) a simple measure of the legal strength of a given CER based on its language. These data come from Jeffords (2013), where the first is operationalized by a simple indicator variable noting if a constitution has a CER provision (denoted by a " 1 ") or does not (denoted by a " 0 "), and the second specification is an additive index of seven keyword categories. Jeffords (2013) examined the constitutions of 198 countries as of 2010 for instances of CER provisions and found that 125 constitutions contain a uniquely written provision. ${ }^{14}$ Each provision was then examined for the presence of seven keyword categories endemic to the literature that defines and outlines ER's. ${ }^{15}$ At the conclusion of the keyword analysis, each constitution was given a simple additive

and EH components. That said, we stick with the 2012 name, but implement our empirical strategies assuming the data is from no later than 2010.

${ }^{14}$ Of particular additional importance is the fact that out of these 125 countries, approximately 20 constitutions contained "negating statements." These are statements that immediately precede or follow a CER provision, as well as additional constitutional provisions, and mitigate or negate the legal strength of the provisions. These negating statements typically note that the following or preceding language is not to be construed as enforceable law but rather as guiding principles for constructing policy. We have not yet empirically accounted for these negating statements, but they often apply to additional provisions beyond the environmental ones.

${ }^{15}$ See Jeffords (2013) for a complete description of this process. 
score across the seven categories. For example, a score of three indicates the presence of three out of the seven categories. The seven keyword categories are listed in the Table 1.

\section{[Insert Table 1 About Here]}

Consider as an example, the CER provision found within the constitution of Mali (1992): Every person has the right to a healthy environment. The protection and defense of the environment and the promotion of the quality of life is a duty of everyone and of the state." The underlined phrases denote the presence of categories 4, 6, and 1, respectively.

Drawing from the constitutions literature, we hypothesize a nonnegative relationship between CER provisions and the EO variables. CER's supply incentives and constraints that should increase policymaker effort in the direction of better environmental outcomes.

\subsection{Control Variables}

To control for the effects of income on environmental outcomes, we use the natural log of purchasing power parity adjusted gross domestic product per capita in constant 2005 international dollars. The data are from The World Bank's World Development Indicators database. We also include the square of this variable to account for potential nonlinearties in protecting the environment as per capita income grows. For example, it could be the case that a relatively young and poor country begins with some EPI score but as income grows, the country pollutes at a faster rate than it can protect the environment and its ranking falls. At some threshold income per capita, however, the country might take steps to protect the environment and the EPI rank begins to climb. In other words, because the way in which the main dependent variables are calculated, they are similar to environmental "goods" and not "bads." Thus we do not expect the typical inverted U-shape found in the EKC literature, but rather a U-Shape. As a result of this "inverted, inverted-U" hypothesis, we expect the sign on the natural log of purchasing power parity adjusted gross domestic product per capita to be negative and positive on the squared term.

To control for a country's willingness to integrate international law into domestic law, we include a dummy variable that indicates if a country is a "state party" to the United Nations International Covenant on Economics, Social, and Cultural Rights (ICESCR). ${ }^{16}$ Articles 11 and 12 of the ICESCR delineate the rights to an adequate standard of living and the enjoyment of the highest attainable standard of physical and mental health, respectively. These two articles often form part of the foundation for defining ER. For example, General Comment 15 ("The Right to Water") of the Committee on Economic, Social, and Cultural Rights (CESCR) is written in part by relying on the fact that having a minimum quantity of water of at least potable quality fulfills aspects of Articles 11 and 12. We expect being a state party to the ICESCR will be nonnegatively related to the EO variables.

In an attempt to control for the quality of legal institutions and also to align with recent EKC studies, we include the rule of law measure. The data for rule of law are from the

\footnotetext{
${ }^{16}$ Being a state party implies accession and/or ratification of the ICESCR, both of which imply the covenant has (in part or in full) been integrated into the law of the country.
} 
Worldwide Governance Indicators project of The World Bank (Kaufmann, et. al, 2010). ${ }^{17}$ According to the variable description, rule of law "reflects perceptions of the extent to which agents have confidence in and abide by the rules of society, and in particular the quality of contract enforcement, property rights, the police, and the courts, as well as the likelihood of crime and violence." The original values range from -2.5 (signifying weak government performance) to +2.5 (signifying strong government performance), however we normalize the variable to the unit interval. We expect rule of law to be nonnegatively related to the environmental outcome variables. ${ }^{18}$

We also control for the population density of each country using population divided by land area (in square kilometers) data from The World Bank's World Development Indicators database. We take the natural log of population density and expect this variable to be nonpositively related to environmental outcomes. For a given land area, the more people there are per square kilometer, the more likely it is that the country experiences relatively poorer environmental outcomes at the national level. This could stem from a resource scarcity problem, for example, or perhaps from an increased likelihood of negative environmental externalities in densely populated areas.

Finally, because we expect the presence of unobserved regional heterogeneity associated with environmental outcomes, we include geographic controls in certain model specifications. We divide the globe into six regions: Africa, North America, South America, Europe, Australia, and Asia. ${ }^{19}$ To avoid the dummy variable trap in the geographic controls specifications, we maintain the regression constant and use Asia as the base category. ${ }^{20}$ We do not have any sign expectations with respect to the geographic controls and suppress the coefficient estimations in the results tables. We simply note if the model includes geographic controls or not. $^{21}$

${ }^{17}$ This is calculated with data from 23 distinct sources such as the Cingranelli-Richards Human Rights Database and Political Terror Scale, World Justice Project Rule of Law Index, and The World bank Country Policy and Institutional Assessments. See Kaufmann, et al (2010) for a full description of methodology behind the Worldwide Governance Indicators project.

${ }^{18}$ In unreported regressions, we used another variable from the Worldwide Governance Indicators project called government effectiveness. This variable "reflects perceptions of the quality of public services, the quality of the civil service and the degree of its independence from political pressures, the quality of policy formulation and implementation, and the credibility of the government's commitment to such policies." The results do not significantly change if we use government effectiveness instead of rule of law, in part because the two variables are highly positively correlated.

${ }^{19}$ In a previous iteration we considered eight regional specifications: North Africa, Sub-Saharan Africa, North America, South America, Eastern Europe and Central Asia, (the rest of) Europe, Asia and the Pacific, and the Middle East. We settled on continent-style regional specifications due to a much smaller data set in this iteration. As a result of the indicator timing issue discussed in Section 3.1, we lost between 40 and 93 observations depending on the model specification, which is a relatively large amount considering the cross-sectional methodology. More information about this change is available from the authors upon request.

${ }^{20}$ We tried every region as the base and the primary estimation results did not change. Of course, the size, sign, and significance of the regional dummies and the constant term fluctuated as measured against the selected base region.

${ }^{21}$ Nonetheless, the results are available from the authors upon request. 


\section{Data and Methodology}

The data consists of observations for roughly 96 countries. Out of these countries, 57 include ER provisions in their constitutions and 39 do not. Owing to various missing data either for the dependent or independent variables, the observation count across the model specifications ranges from 71 to $84 .^{22}$

Our empirical strategy begins with simple ordinary least squares (OLS) regressions of the CER provision variables and control variables on the EO variables in a cross-section framework. ${ }^{23}$ Simple linear regressions of this sort, however, could suffer from a serious endogeneity problem. Because we are concerned about the instances where a country that constitutionalizes ER is also more likely to take better care of the natural environment, we implement a two-stage IV approach. This approach not only controls for measurement error as discussed below, but it also allows us to account for unobservable cultural factors, social norms, and political inclinations that would cause a country to include an ER provision in its constitution but would not directly impact environmental outcomes. If this form of endogeneity exists, we expect the coefficient estimates on the CER variables to be biased in the simple OLS specifications. In what follows we first discuss the simple linear regression framework and then the IV approach.

\subsection{Simple OLS Regression}

The 2012 EPI is constructed using data over the 2000-2010 time period. Therefore, in order to avoid measurement error and the possibility that CER's were added to constitutions after the measured EPI values (or some of its components) for any country, we lag all of the explanatory variables to 1999. While this approach eliminates the possibility of reverse causality, it comes at the cost of reducing the sample size because we exclude those countries that added CER's from the year 2000 forward. $^{24}$

Our cross-sectional framework thus accounts for some simultaneous causality by regressing explanatory variables in period $t$ on dependent variables in period $t+1$ as follows:

$$
Y_{i t+1}=\beta_{o}+E_{i t}^{\prime} \beta_{1}+\boldsymbol{W}_{i t}^{\prime} \boldsymbol{\alpha}+\boldsymbol{D}_{\boldsymbol{i}}^{\prime} \boldsymbol{\delta}+\epsilon_{i t}
$$

\footnotetext{
${ }^{22}$ A complete list of the countries in the data is available in Appendix 2.

${ }^{23}$ Because the structure of EPI has changed multiple times since its formulation and because our primary independent variables do not vary over time, we cannot feasibly consider a panel framework at this point, but leave this analysis for future research.

${ }^{24}$ In separate regressions we included those countries with CER's all the way up until 2010. Those results are reported in Appendix 3. While the benefit is added observations, the problem of course is that for some countries the CER's are likely to have been added after the EPI (or some of its components) were measured. This problem could be mitigated if the EPI indicators are measured using the lowest value available over the 2000-2010 interval. That is explicitly stated in the EPI manual for the "lowest performer" in the target calculation. What remains unclear is if the lowest value over the interval is also used for any other country's base calculation.
} 
where $E$ is one of the two specifications of the CER provision variable and $W$ is a vector of country-specific explanatory variables. We also implement geographic controls in certain model specifications, which are represented by $D .{ }^{25}$ The term $\epsilon_{i t}$ is the typical, independently and identically distributed, normal disturbance term. We estimate Equation (1) with OLS and to find the estimate of $\beta_{1}$.

\subsection{Instrumental Variables Regression}

Our IV approach adopts the included/excluded instruments language to note that included instruments are those explanatory variables which appear in both the first and second stage regressions, and excluded instruments are those that appear only in the first stage regression. Because we expect $E$ is correlated with $u$, we estimate the following first-stage expression with a vector of excluded instruments, $Z$, and the vector of included instruments $W$ :

$$
E_{i t}=\pi_{o}+\boldsymbol{Z}_{\boldsymbol{i t}}^{\prime} \boldsymbol{\theta}+\boldsymbol{W}_{\boldsymbol{i t}}^{\prime} \boldsymbol{\gamma}+\boldsymbol{D}_{\boldsymbol{i}}^{\prime} \boldsymbol{\eta}+u_{i t}
$$

to obtain the predicted values of $E_{i t}$ called $\widehat{E_{t t}}$.

In the second stage, we augment Equation (1) by replacing $E_{i t}$ with $\widehat{E_{l t}}$, and estimate the following:

$$
Y_{i t+1}=\beta_{o}+\widehat{E_{l t}} \beta_{1}+\boldsymbol{W}_{i t}^{\prime} \boldsymbol{\alpha}+\boldsymbol{D}_{\boldsymbol{i}}^{\prime} \boldsymbol{\delta}+\epsilon_{i t} .
$$

Adjusting for the relatively small sample size of the cross-sectional data, equations (2) and (3) are estimated within a generalized method of moments (GMM) framework using a heteroskedastic-robust weighting matrix and a robust variance-covariance matrix (i.e., robust standard errors).

\subsection{Instruments}

Our IV approach includes three exogenous instruments. The reasoning for our instruments draws of the work of Elkins, Ginsburg and Simmons (2013) who show that the International Bill of Human Rights has provided a powerful coordination effect on national constitution makers. ${ }^{26}$ Newer constitutions in particular draw from those sources, and those that do should be more likely to incorporate or add ER's. Our first instrument is a count variable of the number of CER provisions in existence prior to a county writing its own CER provision into its constitution. The second is a count variable of the number of other economic and social rights in a country's constitution. The last is the minimum of the age of the constitution or the CER provision. We explain each of these in turn.

\footnotetext{
${ }^{25}$ The regression constant is maintained and the base region is Asia.

${ }^{26}$ The International Bill of Human Rights includes the Universal Declaration of Human Rights (adopted by the UN General Assembly in 1948), and the International Covenant on Economic, Social, and Cultural Rights and the International Covenant on Civil and political Rights (1976).
} 
Based on the timing of including a CER provision in a given constitution - either at the date the constitution was written or at a later date via amendment - we create a variable that is the sum of the number of constitutions which include a CER provision prior to the current country writing its own CER provision. The fundamental premise for creating and using this variable as an excluded instrument is that constitutional framers tend to read the constitutions of other countries to formulate the language for their own constitution/amendment. We expect that the mere number of CER provisions in existence prior to a country writing its own will not affect the EO variables in the country in question, but that the higher the number, the more likely a country is to include an ER provision in its constitution. This assumption may be strong for some environmental performance aspects, for example in case of pollution which does not respect political, temporal, or geographic boundaries. It could be that the polluting activities within a country with a CER provision do affect the natural environment of other countries which may or may not yet have a CER provision.

Created from proprietary data collected by Minkler, our second instrument is a count variable which indicates the presence of other economic and social rights in a country's constitution. These rights include the right to primary education, the right to social services, the right to work, the right to public employment, the right to just and favorable remuneration, a ban on child labor, the right to social security in the event of unemployment, and the right to social security in the event of old age. Using a dummy variable to denote the presence of each right, we sum across the eight rights to create the count variable that has a minimum of zero, a maximum of eight, and a mean value of 3.6. ${ }^{27}$ We assume that the more economic and social rights a country's constitution has, the more likely it is to constitutionalize ER. There is no immediate reason to assume that these specific rights will affect the EO variables in a given country. If, however, we included rights such as a guaranteed adequate standard of living or the right to adequate food/nutrition, we could not make such an exclusionary assumption.

Our last instrument is the minimum of the age of the constitution or the CER provision as of 2010. First, we expect that any lingering temporal effects of the age of the country/constitution on environmental outcomes are accounted for by the size of income per capita and the geographic controls. Second, because countries that have CER provisions tend to be younger (in constitutional age) than their non-CER counterparts, we expect that the age of a country/constitution is nonpositively related to the inclusion of a CER provision. In other words, the newer the constitution, the more likely it is to have a CER provision akin to the generation effect analyzed by Elkins, Ginsberg, and Simmons (2013).

\section{Results}

The primary estimation results are illustrated in Tables 3-8. Model specifications denoted by a "\#.A" are simple OLS regressions, and the corresponding instrumental variables regressions are by marked by "\#.B".

\subsection{OLS Regression Results}

\footnotetext{
${ }^{27}$ It is important to note that some of these eight rights may be more important than others when considered as mere indicators for the presence of a CER, but we leave this question for future research.
} 
While our main results come from the IV regressions, we first briefly describe the OLS results. For each of the EPI and EV specifications in Tables 3-6, the coefficient estimates on each of the explanatory variables have the expected sign. ${ }^{28}$ The CER variable, however, is only significant in models 3.A and 7.A. With respect to the $\mathrm{EH}$ outcome variable, the models perform well in terms of R-squared and adjusted R-squared as illustrated in Tables 7 and 8, but the coefficient estimate on the CER variable is not statistically significant across the specifications and even has a negative sign in some. This is perhaps not surprising for a few reasons. First, the weight placed on the child mortality indicator within the $\mathrm{EH}$ component is relatively high compared to the other indicators, and child mortality rates depend on, and represent, a host of nonenvironmental factors. For instance, poverty measures like the UNDP's Human Poverty Index explicitly include child mortality as one of its indicators. Secondly, access to sanitation and access to drinking water reports tend to be inaccurate because countries like the United States typically report $100 \%$ access across these categories even though there exists pockets of waterrelated poverty in urban, rural, and mountainous regions of Colorado, for example (Wescoat, et. al., 2007).

The income per capita variables are statistically significant and have the expected signs across the EPI and EV specifications. To a certain extent, this confirms the "inverted inverted- $U$ " hypothesis of the Environmental Kuznet's Curve literature. While the linear term is significant in the EH specifications, it has a sign opposite of our expectations and the squared term is negatively signed and statistically insignificant across all EH specifications. Population density is also relatively unimportant across the EPI and EV specifications, but it does play a somewhat significant role in some of the EH specifications. Being a state party to the ICESCR and the rule of law have the expected signs and are significant only in some of the EPI and EV specifications. Although not shown in the tables, many of the geographic dummies across the model specifications are significant at various levels between $1 \%$ and $10 \%$. The regression constant is also highly statistically significant. These effects could perhaps explain the lack of significance of the other covariates in the specifications that include geographic controls.

\subsection{Instrumental Variables Regression Results}

Across each IV specification for the EPI and its EV component, the coefficient estimates on the CER variables increase in size and attain statistical significance. These results are consistent with the assumed bias on the CER variable coefficients in the simple OLS specifications. The results are also consistent across CER index type. For the full EPI regressions the coefficient on being a party to the ICESCR is significant at the $10 \%$, but rule of law and population density coefficients are insignificant. In contrast, the coefficient estimates for the CER variables within the instrumental variables framework for $\mathrm{EH}$ are insignificant. Again, we think this is because of the choice and weighting of the indicators that form the EH component. The coefficient estimates,

\footnotetext{
${ }^{28}$ We also tested around 20 simpler specifications which built up (step-wise) to the results presented here. The results were largely the same, with very few instances of the CER variables being insignificant. The empirical results of these specifications are available from the authors upon request.
} 
signs, and significance levels remain relatively stable across the other explanatory variables when compared to the simple OLS analogs.

A few questions remain. First, are the instruments significant predictors of the CER variables? This basic question is answered by examining the coefficient estimates from the first stage regressions. Second, are the three instruments valid? That is, are the instruments uncorrelated with the error term in Equation (1)? And third, are they "weak" instruments? The second is addressed by performing Hansen's test of overidentifying restrictions where the null hypothesis is that all instruments are valid. The so-called "J-Statistic" has a chi-squared distribution with degrees of freedom equal to the number of overidentifying restrictions. In this case, the number of overidentifying restrictions is equal to the number of instruments $-1=2$. The third is addressed by applying an F-test of the joint significance of the instruments. ${ }^{29}$ The answers to all three of these questions are found in Table 9 for each instrumental variables model (1.B - 12.B).

In models $1 . B$ to $8 . B$, most of the coefficient estimates on the instrumental variables are significant at either the $1 \%$ or $5 \%$ level, and have the expected sign. ${ }^{30}$ The exception is the constitution/provision age instrument. In part, we think this is because the age of the constitution, while intuitively important for explaining the presence of a CER, can also represent the age of the country where a newer country (time-wise) has had less time, for example, to implement environmental policies to protect the environment. If this is the case, then the age instrument fails to meet the exclusion restriction. ${ }^{31}$ Based on the p-values for Hansen's JStatistic, however, we fail to reject the null hypothesis of valid instruments and conclude that the overidentifying restriction is valid. Finally, based on the p-values for the Robust F-Statistic, we reject the null hypothesis of weak instruments.

In short, and with respect to the CER variables, the comprehensive conclusions we can draw from these results are: (1) the presence of a CER leads to improved environmental outcomes as measured by EPI and EV; $(2)$ the presence and strength of the CER language lead to improved environmental outcomes as measured by EPI and EV; (3) our instruments are relatively significant predictors of why a country includes an ER provision (and of a certain language) in its constitution; and (4) all three of our instruments are valid and not weak.

\subsection{Including Countries with CER's up to 2010}

As noted earlier, because of the way the EPI is constructed, we had to date all control variables to 1999 and only use only those countries with CER's up until that time. We did this to

\footnotetext{
${ }^{29}$ A weak instrument is a poor predictor of the endogenous variable which, in this case, is the CER variable in each specification. For more on the nature of "weak" instruments, see Staiger and Stock (1997) and Stock and Yogo (2005).

${ }^{30}$ Because the results of the instrumental variables regression for the EH outcome variable were largely insignificant, we do not discuss the first stage results and statistics but merely present them in Table 9.

${ }^{31}$ Again, to be consistent with previous research in this area (e.g., Persson and Tabellini, 2000), we include age as an instrument. Empirical specifications with age as an included instrument weakened the overall significance of both the simple OLS results and the IV results. We therefore keep age as an excluded instrument, but make available upon request the regression results with age as an included instrument, or left out of the empirical analysis altogether.
} 
avoid/mitigate possible measurement error. In this specification, in order to increase the sample size, we also included those countries that added CER's from 1999-2010 (the last year of the $2012 \mathrm{EPI}$ data range). Those results, which likely contain some measurement error, are reported in Appendix 3. They too confirm our main results. Note that the observation count across the empirical specifications has increased and ranges from 100-120.

\subsection{Repeating the Above Empirical Analyses Using the 2014 EPI Data}

We conducted an identical analysis for the 2014 EPI release changing only the dependent variables to their corresponding 2014 values. As noted above the 2014 release had similar calculation methodology thereby forcing us to use data from 1999 for the independent variables. Nonetheless, the results are consistent with the main results just reported, lending further support to our framework. The 2014 EPI results are presented in Appendix 4. Note that the observation count ranges from 87 to 123 depending on the empirical specification.

\section{Policy Implications}

If EPI and its components measure country-level performance of environmental outcomes, then our evidence suggests that CER provisions do lead to increased performance. CER's matter because they affect policymaker incentives, which in turn promotes specific statutory law and regulation sensitive to a country's particular circumstances. The lesson, of course, is that we need to pay attention to the incentives confronting policymakers as well as those agents who are the target of environmental policy (e.g., those who would conserve or polluters). In this, our results support Boyd's (2012) comprehensive, largely qualitative study.

It is important to emphasize that our results do not support unqualified implementation of CER's as a strategy to increase a country's environmental performance. While the results suggest some positive benefits, our analysis does not attempt to incorporate the cost of CER implementation. The widespread prevalence of CER's may suggest that the anticipated benefits outweigh the costs of implementation in many cases, for some countries for some environmental provisions it is unlikely to be true. The political opposition to implementing a federal CER (any CER!) in the US would be enormous (although a handful of state constitutions include ER provisions such as Pennsylvania, Montana, and Massachusetts). Environmental supporters may more effectively spend their time, resources and energy on statutory law and regulation not only at the federal level, but at the state and municipal levels as well. And while the rule of law variable was not significant in our general EPI or EV regressions, it was in the EH ones, which suggests that some countries, in Africa for instance, may be better off shoring up their legal institutions before (or perhaps concomitant with) expending effort on CER implementation.

Of course there are methodological caveats associated with any initial study such as this one. First, and most importantly, future work needs to find general environmental performance indices that are transparent, sensitive to country heterogeneity, and, in the best case, consistent and measurable over time (to enable panel analysis). The EPI is the best measure currently available, but its validity needs checking. Second, while our CER index variables are 
objectively measured, they are perhaps a bit too simple. In future specifications, we will have to consider the differences in keyword categories to see if some are more important than others in providing the CER provision with legal teeth. As it stands, our count index equally weights all keyword/language categories. We could also try different index constructions, those afforded by principal component analysis for instance. Finally, future research could account for additional institutional, sociodemographic, economic factors, and legal events at the country level. These include, for instance, a country's legal origins, governmental and nongovernmental organizations tasked with protecting the environment, type of government, natural resource endowments, aspects of international trade, and statutory law, regulation, and court decisions. 


\section{References}

Acemoglu, D. (2005) “Constitutions, Politics, and Economics: A Review Essay on Persson and Tabellini's The Economic Effects of Constitution," Journal of Economic Literature V. XLIII pp. 1025-1048.

Acemoglu, D., Johnson, S., and Robinson, J. (2001) "The Colonial Origins of Comparative Development: An Empirical Invesigation," American Economic Review 91(5), 1369-1401.

Buchanan, J. and Brennan, G. (1981) The Reason of Rules: Constitutional Political Economy. Cambridge University Press.

Bhattarai, M. and Hammig, M. (2001) "Institutions and the Environmental Kuznets Curve for Deforestation: A Cross Country Analysis for Latin America, Africa, and Asia," World Development, 29(6), 995-1010.

Boyd, David R., 2012. The Environmental Rights Revolution: A Global Study of Constitutions, Human Rights, and the Environment, Vancouver: UBC Press.

Castiglione, C, Infante, D., and Smirnova, J. (2012) "Rule of Law and the Environmental Kuznets Curve: Evidence for Carbon Emissions," International Journal of Sustainable Economy 4(3), 254-269.

Chen, M. (2010) "Rule of Law and Environmental Policy Stringency," Working Paper 10-3, Institute for the Study of International Aspects of Competition, University of Rhode Island.

Donnelly, Jack, 2003. Universal Human Rights in Theory and Practice, Ithaca: Cornell University Press.

Dworkin, R. (1977) Taking Rights Seriously, Cambridge: Harvard University Press.

Elkins, Z., Ginsburg, T., and Simmons, N. (2013) “Getting to Rights: Treaty Ratification, Constitutional Convergence, and Human Rights Practice," Harvard International Law Journal, V. 54.

Elster, J. (1995) "The Impact of Constitutions on Economic Performance," Proceedings of the World Bank Annual Conference on Development Economics 1994, The International Bank for Reconstruction and Development, The World Bank.

Emerson, J.W., Hsu, A., Levy, M.A., de Sherbinin, A., Mara, V., Esty, D.C., and Jaiteh, M. (2012) "2012 Environmental Performance Index and Pilot Trend Environmental Performance Index," New Haven: Yale Center for Environmental Law and Policy. 
Emerson, J.W., Hsu, A., Levy, M.A., de Sherbinin, A., Mara, V., Esty, D.C., and Jaiteh, M. (2012) "2012Environmental Performance Index Summary for Policy Makers," New Haven: Yale Center for Environmental Law and Policy.

Ewing, B., S. Goldfinger, M. Wackernagel, M. Stechbart, S.M. Rizk, A. Reed, and J. Kitzes, 2008. The Ecological Footprint Atlas 2008. Okland: Global Footprint Network.

Goulder, L. and Parry, I. (2008) "Instrument Choice in Environmental Policy," Review of Environmental Economics and Policy 2(2), 152-174.

Hiskes, R. (2009) The Human Right to a Green Future. Cambridge University Press.

Jeffords, C. (2013) "Constitutional Environmental Human Rights: A Descriptive Analysisof 142 National Constitutions," in L. Minkler (ed.), The State of Economic and Social Human Rights: A Global Overview. Cambridge University Press.

Kaufmann, D., Kraay, A., and Mastruzzi, M. (2010) "The Worldwide Governance Indicators: A Summary of Methodology, Data, and Analytical Issues," World Bank Policy Research Working Paper No. 5430.

La Porta, R, Lopez-de-Silanes, F., and Shleifer,A. (2008) "The Economic Consequences of Legal Origins," Journal of Economic Literature XLVI (2), 285-332.

Minkler, L. (2009) "Economic Rights and Political Decision-Making," Human Rights Quarterly $32(2), 368-393$.

North, D. and Weingast, B. (1989) "Constitutions and Commitment: The Evolution of Institutions Governing Public Choice in Seventeenth-Century England," The Journal of Economic History, Vol. XLIX, No. 4

Osiatynski, W. (2007) "Needs-Based Approach to Social and Economicc Rights," in Hertel, Shareen and Lanse Minkler (Eds), Economic Rights: Conceptual, Measurement. And Policy Issues, Cambridge: Cambridge University Press.

Persson, T. and Tabellini, G. (2000) The Economic Effects of Constitutions, MIT Press.

Sokoloff, K. and Engerman, S. (2000) "Institutions, Factor Endowments, and Paths of Development in the New World," Journal of Economic Perspectives 14(3), 217-232.

Spolaore, E. and Wacziarg, R. (2013) "How Deep are the Roots of Economic Development?," Journal of Economic Literature 51(2), 325-369.

Staiger, D. and Stock, J. (1997) "Instrumental Variables Regression with Weak Instruments", Econometrica 65, 557-586. 
Stock, J.H. and Yogo, M. (2005) "Testing for Weak Instruments in Linear IV Regression,'Chapter 5 in Identification and Inference in Econometric Models: Essays in Honor of Thomas J. Rothenberg, Andrews and Stock (eds.).

Thompson, Alexi, 2012. Three Essays on the Environmental Kuznets Curve for Water Pollution, Unpublished Ph.D. Dissertation, Kansas State University.

Wescoat, J. Jr., Headington, L., and Theobald, R. (2007) "Water and Poverty in the United States," Geoforum 38(5): 801-814.

World Bank, World Development Indicators Database, accessed Fall 2013.

United Nations: (2002) General Comment 15 ("The Right to Water") of the Committee on Economic, Social, and Cultural Rights.

United Nations: International Covenant on Economic, Social, and Cultural Rights, (adopted by General Assembly resolution 2200 (XXI) of December 16, 1966). 


\section{Appendix 1 - Main Supporting Figures and Tables}

\section{Figure 1 - EPI Indicator Framework with Weights for Aggregation}

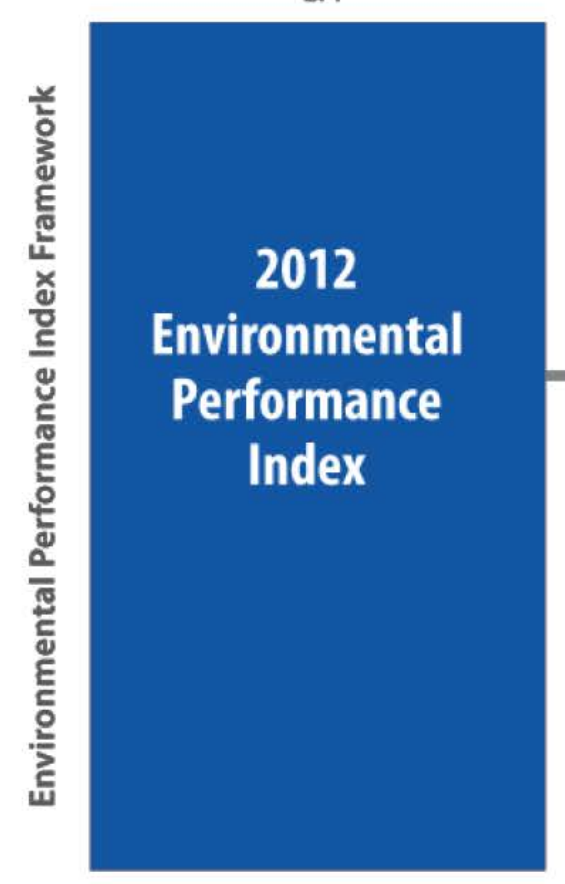

OBJECTIVES

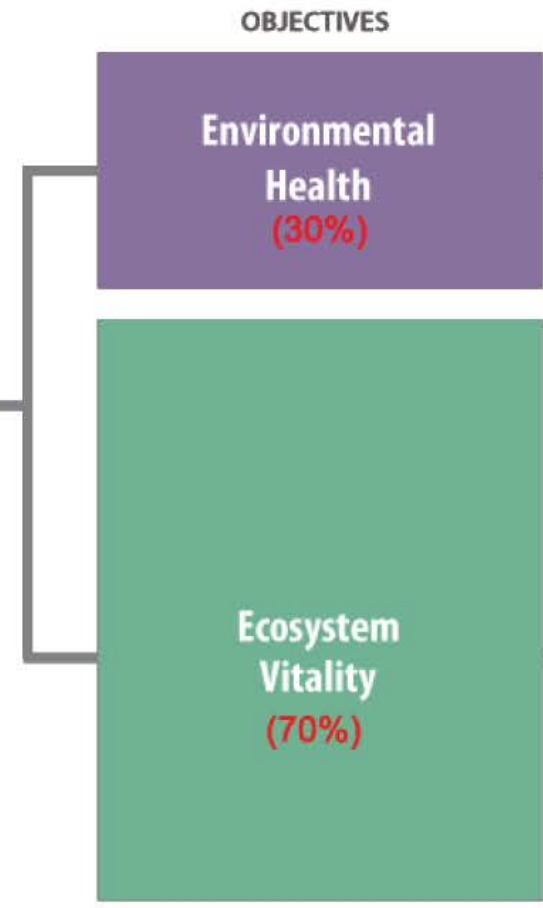

POLICY CATEGORIES
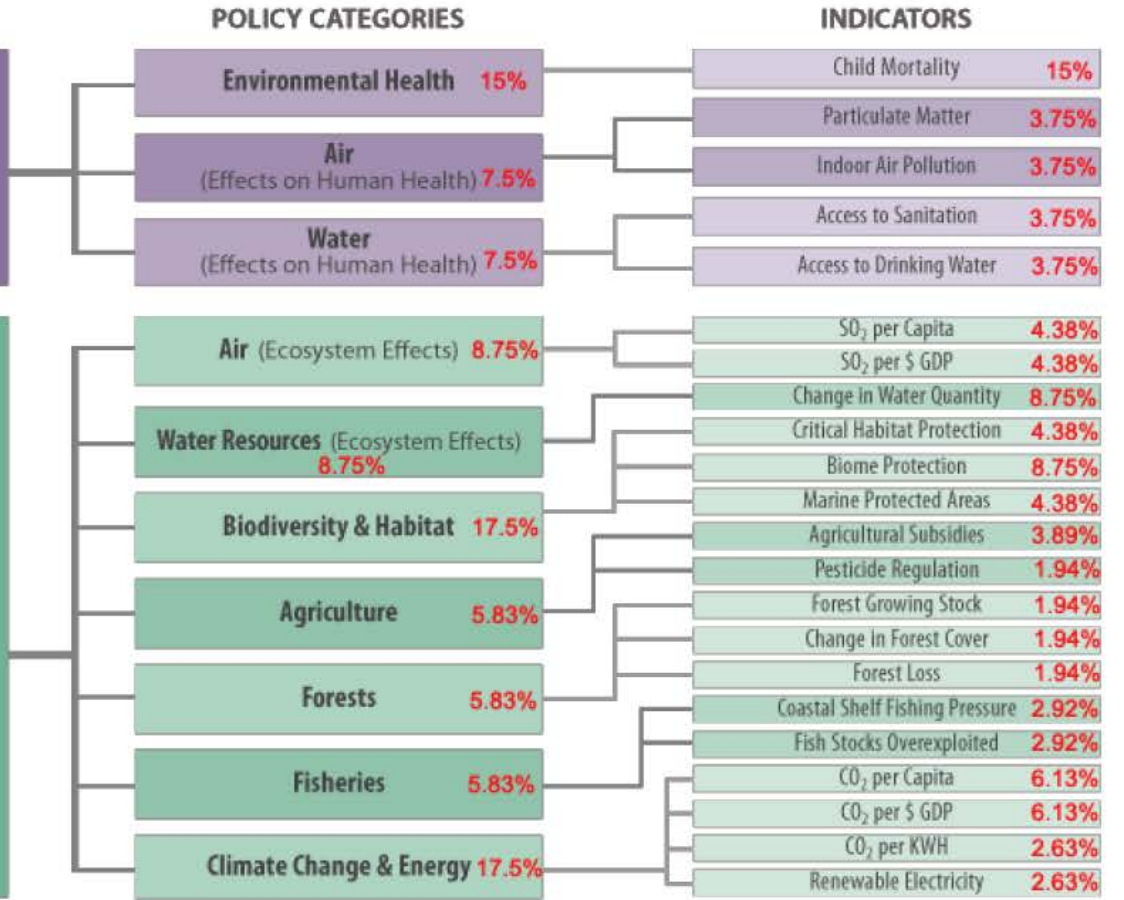
Table 1 - Descriptions of the Seven Keyword Categories

\begin{tabular}{lll}
\hline Category & Brief Description & General Keywords (Non-Exhaustive List) \\
\hline 1 & Strong language associated with state/government responsibility & Duty, obligation, protection, etc. \\
2 & Weak language associated with state/government responsibility & Shall ensure, take measures, fundamental objective, etc. \\
3 & Right of citizen's to be informed about the status of the environment & Informed, information, etc. \\
4 & Citizen's right to a clean or health environment & Future, generations, sustainable, etc. \\
5 & Concern for future generations and/or sustainable development & Citizen, duty, everyone, etc. \\
6 & Citizen's and "everyone's" responsibility to protect the environment & Water, right, clean, pure, etc. \\
7 & Explicit human right to water & \\
\hline
\end{tabular}


Table 2 - Descriptive Statistics for the Dependent, Control, and Instrumental Variables

\begin{tabular}{|c|c|c|c|c|c|}
\hline & \multicolumn{5}{|c|}{ Summary Statistics } \\
\hline & Observations & Mean & Standard Deviation & Minimum & Maximum \\
\hline \multicolumn{6}{|l|}{ Dependent Variables } \\
\hline Environmental Performance Index & 74 & 54.12 & 9.87 & 32.24 & 69.92 \\
\hline Ecosystem Vitality & 74 & 48.23 & 11.13 & 19.76 & 69.48 \\
\hline Environmental Health & 88 & 63.47 & 28.39 & 13.46 & 100.00 \\
\hline \multicolumn{6}{|l|}{ Primary Independent Variables } \\
\hline Has CER Provision & 96 & 0.594 & 0.494 & 0 & 1 \\
\hline Index 0-7 & 96 & 1.385 & 1.372 & 0 & 4 \\
\hline \multicolumn{6}{|l|}{ Control Variables } \\
\hline In GDP/Capita & 89 & 8.683 & 1.237 & 6.22 & 10.95 \\
\hline In GDP/Capita Squared & 89 & 76.91 & 21.212 & 38.70 & 119.96 \\
\hline Party to ICESCR & 96 & 0.969 & 0.175 & 0 & 1 \\
\hline Rule of Law & 96 & 0.523 & 0.209 & 0.086 & 0.894 \\
\hline In Pop. Density & 95 & 4.021 & 1.577 & 0.425 & 9.674 \\
\hline Africa & 96 & 0.271 & 0.447 & 0 & 1 \\
\hline North America & 96 & 0.115 & 0.320 & 0 & 1 \\
\hline South America & 96 & 0.104 & 0.307 & 0 & 1 \\
\hline Europe & 96 & 0.292 & 0.457 & 0 & 1 \\
\hline Australia & 96 & 0.031 & 0.175 & 0 & 1 \\
\hline Asia & 96 & 0.188 & 0.392 & 0 & 1 \\
\hline \multicolumn{6}{|l|}{ Instrumental Variables } \\
\hline ER Count Before & 96 & 20.09 & 23.02 & 0 & 66 \\
\hline Count of Other ESR & 96 & 3.50 & 2.39 & 0 & 8 \\
\hline Constitution/Provision Age & 96 & 22.54 & 32.79 & 1 & 213 \\
\hline
\end{tabular}


Table 3 - Full Environmental Performance Index and Has/Doesn't Have CER

\begin{tabular}{|c|c|c|c|c|}
\hline & \multicolumn{4}{|c|}{ LHS Variable: Environmental Performance Index } \\
\hline & Model (1.A) & Model (1.B) & Model (2.A) & Model (2.B) \\
\hline \multirow[t]{2}{*}{ Has CER Provision } & 2.711 & $6.828 * * *$ & 1.364 & $6.023^{* *}$ \\
\hline & $(1.777)$ & $(2.381)$ & $(2.108)$ & $(2.821)$ \\
\hline \multirow[t]{2}{*}{ In GDP/Capita } & $-21.88 *$ & $-23.81 * *$ & $-24.92 * *$ & $-28.78 * *$ \\
\hline & $(11.12)$ & $(10.55)$ & $(11.59)$ & $(10.98)$ \\
\hline \multirow[t]{2}{*}{ In GDP/Capita Sq. } & $1.476^{* *}$ & $1.611^{* *}$ & $1.549 * *$ & $1.835^{* * *}$ \\
\hline & $(0.672)$ & $(0.640)$ & $(0.710)$ & $(0.675)$ \\
\hline \multirow[t]{2}{*}{ Party to ICESCR } & 7.021 & $9.686^{*}$ & 7.339 & $11.25^{*}$ \\
\hline & $(6.644)$ & $(5.710)$ & $(5.905)$ & $(5.851)$ \\
\hline \multirow[t]{2}{*}{ Rule of Law (1998) } & 12.82 & 12.79 & $15.44^{*}$ & 13.20 \\
\hline & (8.598) & $(8.823)$ & $(9.011)$ & $(9.286)$ \\
\hline \multirow[t]{2}{*}{ In Pop. Density } & 0.147 & 0.233 & 0.246 & 0.484 \\
\hline & $(0.615)$ & $(0.641)$ & $(0.672)$ & $(0.698)$ \\
\hline \multirow[t]{2}{*}{ Constant } & $114.2^{* *}$ & $114.9 * *$ & $129.1^{* *}$ & $134.5^{* * *}$ \\
\hline & $(47.58)$ & $(45.42)$ & $(49.37)$ & $(48.02)$ \\
\hline Observations & 71 & 71 & 71 & 71 \\
\hline Geographic Controls & No & No & Yes & Yes \\
\hline R-squared & 0.524 & 0.482 & 0.603 & 0.554 \\
\hline Adjusted R-squared & 0.479 & 0.433 & 0.529 & 0.471 \\
\hline
\end{tabular}

Note(s): LHS variable as of 2012. RHS variables as of 1999.

Models with ".B" notation are the second stage results from IV regression.

Standard errors in parentheses

P-Value Notation: * $p<0.10, * * p<0.05, * * * p<0.01$ 


\section{Table 4 - Full Environmental Performance Index and CER Index 0-7}

\begin{tabular}{lllll}
\hline & \multicolumn{4}{c}{ LHS Variable: Environmental Performance Index } \\
& Model (3.A) & Model (3.B) & Model (4.A) & Model (4.B) \\
\hline Index 0-7 & $1.230^{* *}$ & $2.458^{* * *}$ & 0.671 & $2.279^{* *}$ \\
& $(0.599)$ & $(0.877)$ & $(0.675)$ & $(1.077)$ \\
In GDP/Capita & $-22.64^{* *}$ & $-23.68^{* *}$ & $-25.08^{* *}$ & $-27.05^{* *}$ \\
& $(10.75)$ & $(10.44)$ & $(11.39)$ & $(11.21)$ \\
In GDP/Capita Sq. & $1.516^{* *}$ & $1.577^{* *}$ & $1.557^{* *}$ & $1.708^{* *}$ \\
& $(0.650)$ & $(0.634)$ & $(0.692)$ & $(0.681)$ \\
Party to ICESCR & 7.309 & $10.74^{*}$ & 7.430 & $11.27^{*}$ \\
& $(6.808)$ & $(5.750)$ & $(6.046)$ & $(6.073)$ \\
Rule of Law (1998) & 13.01 & 14.10 & $15.31^{*}$ & 14.10 \\
& $(8.531)$ & $(8.623)$ & $(8.904)$ & $(9.053)$ \\
In Pop. Density & 0.263 & 0.472 & 0.288 & 0.618 \\
& $(0.609)$ & $(0.628)$ & $(0.643)$ & $(0.667)$ \\
Constant & $116.9 * *$ & $114.6^{* *}$ & $129.7^{* *}$ & $128.9^{* *}$ \\
& $(45.96)$ & $(44.67)$ & $(49.02)$ & $(49.01)$ \\
Observations & 71 & 71 & 71 & 71 \\
Geographic Controls & No & No & Yes & Yes \\
R-squared & 0.533 & 0.502 & 0.606 & 0.561 \\
Adjusted R-squared & 0.490 & 0.455 & 0.533 & 0.479 \\
\hline
\end{tabular}

Note(s): LHS variable as of 2012. RHS variables as of 1999.

Models with ".B" notation are the second stage results from IV regression.

Standard errors in parentheses

P-Value Notation: * $p<0.10, * * p<0.05, * * * p<0.01$ 
Table 5 - Ecosystem Vitality Component/Objective and Has/Doesn't Have CER

\begin{tabular}{|c|c|c|c|c|}
\hline & \multicolumn{4}{|c|}{ LHS Variable: Ecosystem Vitality Component } \\
\hline & Model (5.A) & Model (5.B) & Model (6.A) & Model (6.B) \\
\hline \multirow[t]{2}{*}{ Has CER Provision } & 3.797 & $9.107^{* * *}$ & 2.909 & $8.938 * *$ \\
\hline & $(2.752)$ & $(3.222)$ & $(3.033)$ & $(3.779)$ \\
\hline \multirow[t]{2}{*}{ In GDP/Capita } & $-46.58 * * *$ & $-47.65^{* * *}$ & $-50.78 * * *$ & $-54.72 * * *$ \\
\hline & $(17.01)$ & $(16.81)$ & $(18.08)$ & $(17.18)$ \\
\hline \multirow[t]{2}{*}{ In GDP/Capita Sq. } & $2.581^{* *}$ & $2.660 * *$ & $2.780 * *$ & $3.069 * * *$ \\
\hline & $(1.027)$ & $(1.020)$ & $(1.099)$ & $(1.051)$ \\
\hline \multirow[t]{2}{*}{ Party to ICESCR } & 5.093 & 6.576 & 9.533 & 12.19 \\
\hline & $(6.845)$ & $(7.297)$ & $(6.917)$ & (7.918) \\
\hline \multirow[t]{2}{*}{ Rule of Law (1998) } & 7.166 & 8.347 & 11.86 & 9.708 \\
\hline & $(12.36)$ & $(12.88)$ & $(13.06)$ & $(13.47)$ \\
\hline \multirow[t]{2}{*}{ In Pop. Density } & -0.817 & -0.682 & 0.0569 & 0.419 \\
\hline & $(0.941)$ & $(0.974)$ & $(0.935)$ & $(0.973)$ \\
\hline \multirow[t]{2}{*}{ Constant } & $246.7^{* * *}$ & $243.7^{* * *}$ & $251.0 * * *$ & $256.5^{* * *}$ \\
\hline & $(73.07)$ & $(72.00)$ & $(78.08)$ & $(74.46)$ \\
\hline Observations & 71 & 71 & 71 & 71 \\
\hline Geographic Controls & No & No & Yes & Yes \\
\hline R-squared & 0.160 & 0.109 & 0.341 & 0.280 \\
\hline Adjusted R-squared & 0.081 & 0.025 & 0.218 & 0.146 \\
\hline \multicolumn{5}{|c|}{ Note(s): LHS variable as of 2012. RHS variables as of 1999.} \\
\hline \multirow{2}{*}{\multicolumn{5}{|c|}{$\begin{array}{l}\text { Models with ".B" notation are the second stage results from IV regression. } \\
\text { Standard errors in parentheses }\end{array}$}} \\
\hline & & & & \\
\hline \multicolumn{5}{|c|}{ P-Value Notation: $* p<0.10, * * p<0.05, * * * p<0.01$} \\
\hline
\end{tabular}


Table 6 - Ecosystem Vitality Component/Objective and CER Index 0-7

\begin{tabular}{lllll}
\hline & \multicolumn{5}{c}{ LHS Variable: Ecosystem Vitality Component } \\
& Model (7.A) & Model (7.B) & Model (8.A) & Model (8.B) \\
\hline Index 0-7 & $1.837^{* *}$ & $3.343^{* * *}$ & 1.165 & $3.408^{* *}$ \\
& $(0.919)$ & $(1.216)$ & $(0.959)$ & $(1.448)$ \\
In GDP/Capita & $-47.94^{* * *}$ & $-47.74^{* * *}$ & $-50.65^{* * *}$ & $-52.56^{* * *}$ \\
& $(16.56)$ & $(16.89)$ & $(17.94)$ & $(18.03)$ \\
In GDP/Capita Sq. & $2.655^{* * *}$ & $2.638^{* *}$ & $2.763^{* *}$ & $2.914^{* * *}$ \\
& $(0.997)$ & $(1.020)$ & $(1.079)$ & $(1.085)$ \\
Party to ICESCR & 5.451 & 8.093 & 9.761 & 12.84 \\
& $(7.086)$ & $(7.091)$ & $(6.962)$ & $(7.995)$ \\
Rule of Law (1998) & 7.410 & 9.200 & 11.82 & 10.29 \\
& $(12.27)$ & $(12.62)$ & $(12.80)$ & $(12.99)$ \\
In Pop. Density & -0.639 & -0.373 & 0.0986 & 0.616 \\
& $(0.949)$ & $(0.958)$ & $(0.901)$ & $(0.920)$ \\
Constant & $251.4^{* * *}$ & $244.1^{* * *}$ & $251.2^{* * *}$ & $249.0^{* * *}$ \\
& $(71.29)$ & $(71.98)$ & $(78.37)$ & $(78.31)$ \\
Observations & 71 & 71 & 71 & 71 \\
Geographic Controls & No & No & Yes & Yes \\
R-squared & 0.181 & 0.146 & 0.345 & 0.279 \\
Adjusted R-squared & 0.104 & 0.066 & 0.222 & 0.145 \\
\hline
\end{tabular}

Note(s): LHS variable as of 2012. RHS variables as of 1999.

Models with ".B" notation are the second stage results from IV regression.

Standard errors in parentheses

P-Value Notation: * $p<0.10,{ }^{* *} p<0.05, * * * p<0.01$ 
Table 7 - Environmental Health Component/Objective and Has/Doesn't Have CER Index

\begin{tabular}{|c|c|c|c|c|}
\hline & \multicolumn{4}{|c|}{ LHS Variable: Environmental Health Component } \\
\hline & Model (9.A) & Model (9.B) & Model (10.A) & Model (10.B) \\
\hline \multirow[t]{2}{*}{ Has CER Provision } & 2.153 & 4.472 & -1.511 & 0.652 \\
\hline & $(2.607)$ & $(3.673)$ & $(2.377)$ & $(3.265)$ \\
\hline \multirow[t]{2}{*}{ In GDP/Capita } & $38.16^{* * *}$ & $35.32 * *$ & $32.53 * *$ & $30.08^{*}$ \\
\hline & $(14.27)$ & $(14.76)$ & $(16.17)$ & $(16.54)$ \\
\hline \multirow[t]{2}{*}{ In GDP/Capita Sq. } & -1.277 & -1.041 & -1.202 & -1.012 \\
\hline & $(0.887)$ & $(0.914)$ & $(0.983)$ & $(1.009)$ \\
\hline \multirow[t]{2}{*}{ Party to ICESCR } & 10.67 & 7.041 & 3.801 & 3.005 \\
\hline & $(8.025)$ & $(8.625)$ & $(5.376)$ & $(6.081)$ \\
\hline \multirow[t]{2}{*}{ Rule of Law (1998) } & $32.21 * *$ & $26.01 * *$ & $32.97 * * *$ & $30.56 * *$ \\
\hline & $(13.10)$ & $(12.07)$ & $(12.02)$ & $(12.43)$ \\
\hline \multirow[t]{2}{*}{ In Pop. Density } & $2.372 * * *$ & $2.268 * * *$ & 1.054 & 1.039 \\
\hline & $(0.842)$ & $(0.788)$ & $(0.714)$ & $(0.664)$ \\
\hline \multirow[t]{2}{*}{ Constant } & $-206.4^{* * *}$ & $-194.2 * * *$ & $-147.7^{* *}$ & $-140.0 * *$ \\
\hline & $(58.30)$ & $(59.23)$ & $(67.58)$ & $(68.51)$ \\
\hline Observations & 84 & 84 & 84 & 84 \\
\hline Geographic Controls & No & No & Yes & Yes \\
\hline R-squared & 0.864 & 0.861 & 0.901 & 0.900 \\
\hline Adjusted R-squared & 0.853 & 0.851 & 0.886 & 0.885 \\
\hline \multicolumn{5}{|c|}{ Note(s): LHS variable as of 2012. RHS variables as of 1999.} \\
\hline \multirow{2}{*}{\multicolumn{5}{|c|}{$\begin{array}{l}\text { Models with ".B" notation are the second stage results from IV regression. } \\
\text { Standard errors in parentheses }\end{array}$}} \\
\hline & & & & \\
\hline \multicolumn{5}{|c|}{ P-Value Notation: $* \mathrm{p}<0.10, * * \mathrm{p}<0.05, * * * \mathrm{p}<0.01$} \\
\hline
\end{tabular}


Table 8 - Environmental Health Component/Objective and CER Index 0-7

\begin{tabular}{|c|c|c|c|c|}
\hline & \multicolumn{4}{|c|}{ LHS Variable: Environmental Health Component } \\
\hline & Model (11.A) & Model (11.B) & Model (12.A) & Model (12.B) \\
\hline \multirow[t]{2}{*}{ Index 0-7 } & 0.298 & 1.741 & -0.455 & 0.171 \\
\hline & $(0.913)$ & (1.377) & (0.819) & (1.166) \\
\hline \multirow[t]{2}{*}{ In GDP/Capita } & $39.14^{* * *}$ & $36.76^{* *}$ & $31.93 *$ & $30.51^{*}$ \\
\hline & $(14.26)$ & $(14.90)$ & $(16.04)$ & $(16.17)$ \\
\hline \multirow[t]{2}{*}{ In GDP/Capita Sq. } & -1.348 & -1.138 & -1.158 & -1.042 \\
\hline & $(0.888)$ & $(0.921)$ & $(0.974)$ & $(0.982)$ \\
\hline \multirow[t]{2}{*}{ Party to ICESCR } & 11.15 & 7.395 & 3.696 & 3.205 \\
\hline & (7.626) & $(8.630)$ & $(5.382)$ & $(5.965)$ \\
\hline \multirow[t]{2}{*}{ Rule of Law (1998) } & $32.69 * *$ & $27.16^{* *}$ & $32.67 * * *$ & $30.87 * *$ \\
\hline & $(13.33)$ & $(12.16)$ & $(12.05)$ & $(12.27)$ \\
\hline \multirow[t]{2}{*}{ In Pop. Density } & $2.348 * * *$ & $2.432^{* * *}$ & 1.063 & 1.032 \\
\hline & $(0.871)$ & $(0.839)$ & $(0.729)$ & $(0.666)$ \\
\hline \multirow[t]{2}{*}{ Constant } & $-209.3 * * *$ & $-200.5^{* * *}$ & $-146.0 * *$ & $-141.5^{* *}$ \\
\hline & $(58.63)$ & $(59.70)$ & $(67.32)$ & $(67.32)$ \\
\hline Observations & 84 & 84 & 84 & 84 \\
\hline Geographic Controls & No & No & Yes & Yes \\
\hline R-squared & 0.863 & 0.858 & 0.901 & 0.901 \\
\hline Adjusted R-squared & 0.852 & 0.847 & 0.886 & 0.885 \\
\hline \multicolumn{5}{|c|}{ Note(s): LHS variable as of 2012. RHS variables as of 1999.} \\
\hline \multirow{2}{*}{\multicolumn{5}{|c|}{$\begin{array}{l}\text { Models with ".B" notation are the second stage results from IV regression. } \\
\text { Standard errors in parentheses }\end{array}$}} \\
\hline & & & & \\
\hline \multicolumn{5}{|c|}{ P-Value Notation: $* p<0.10, * * p<0.05, * * * p<0.01$} \\
\hline
\end{tabular}


Table 9 - Selected First-Stage Instrumental Variables Results and Test Statistics

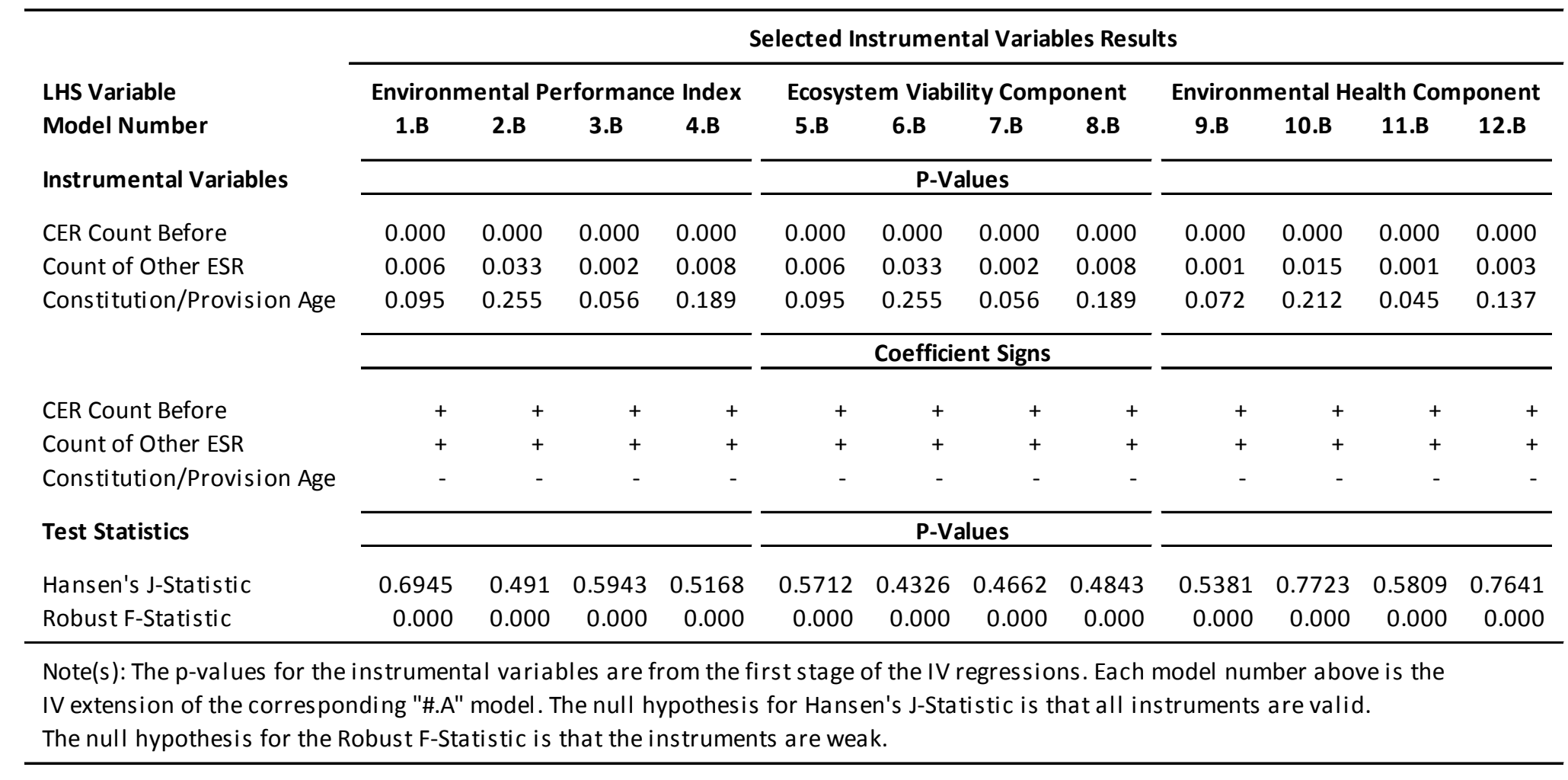




\begin{tabular}{|c|c|c|c|c|c|c|c|c|}
\hline \multirow[b]{2}{*}{ Country } & \multirow[b]{2}{*}{$\begin{array}{l}\text { Has CER } \\
\text { Provision }\end{array}$} & \multirow[b]{2}{*}{$\begin{array}{c}\text { Index } \\
0-7\end{array}$} & \multicolumn{6}{|c|}{ Region } \\
\hline & & & Africa & Asia & Australia & Europe & $\begin{array}{c}\text { North } \\
\text { America }\end{array}$ & $\begin{array}{c}\text { South } \\
\text { America }\end{array}$ \\
\hline Albania & 1 & 2 & 0 & 0 & 0 & 1 & 0 & 0 \\
\hline Algeria & 0 & 0 & 1 & 0 & 0 & 0 & 0 & 0 \\
\hline Angola & 1 & 2 & 1 & 0 & 0 & 0 & 0 & 0 \\
\hline Argentina & 1 & 4 & 0 & 0 & 0 & 0 & 0 & 1 \\
\hline Australia & 0 & 0 & 0 & 0 & 1 & 0 & 0 & 0 \\
\hline Austria & 0 & 0 & 0 & 0 & 0 & 1 & 0 & 0 \\
\hline Bangladesh & 0 & 0 & 0 & 1 & 0 & 0 & 0 & 0 \\
\hline Barbados & 0 & 0 & 0 & 0 & 0 & 0 & 1 & 0 \\
\hline Benin & 1 & 3 & 1 & 0 & 0 & 0 & 0 & 0 \\
\hline Bosnia and Herzegovina & 0 & 0 & 0 & 0 & 0 & 1 & 0 & 0 \\
\hline Brazil & 1 & 3 & 0 & 0 & 0 & 0 & 0 & 1 \\
\hline Cambodia & 1 & 1 & 0 & 1 & 0 & 0 & 0 & 0 \\
\hline Cameroon & 1 & 3 & 1 & 0 & 0 & 0 & 0 & 0 \\
\hline Canada & 0 & 0 & 0 & 0 & 0 & 0 & 1 & 0 \\
\hline Cape Verde & 1 & 4 & 1 & 0 & 0 & 0 & 0 & 0 \\
\hline Chad & 1 & 3 & 1 & 0 & 0 & 0 & 0 & 0 \\
\hline Chile & 1 & 2 & 0 & 0 & 0 & 0 & 0 & 1 \\
\hline Colombia & 1 & 4 & 0 & 0 & 0 & 0 & 0 & 1 \\
\hline Costa Rica & 1 & 3 & 0 & 0 & 0 & 0 & 1 & 0 \\
\hline Croatia & 1 & 2 & 0 & 0 & 0 & 1 & 0 & 0 \\
\hline Cyprus & 0 & 0 & 0 & 1 & 0 & 0 & 0 & 0 \\
\hline Czech Republic & 1 & 1 & 0 & 0 & 0 & 1 & 0 & 0 \\
\hline Denmark & 0 & 0 & 0 & 0 & 0 & 1 & 0 & 0 \\
\hline Dominica & 0 & 0 & 0 & 0 & 0 & 0 & 1 & 0 \\
\hline Equatorial Guinea & 0 & 0 & 1 & 0 & 0 & 0 & 0 & 0 \\
\hline Estonia & 1 & 1 & 0 & 0 & 0 & 1 & 0 & 0 \\
\hline Ethiopia & 1 & 3 & 1 & 0 & 0 & 0 & 0 & 0 \\
\hline Finland & 1 & 2 & 0 & 0 & 0 & 1 & 0 & 0 \\
\hline France & 0 & 0 & 0 & 0 & 0 & 1 & 0 & 0 \\
\hline Gabon & 0 & 0 & 1 & 0 & 0 & 0 & 0 & 0 \\
\hline Germany & 1 & 2 & 0 & 0 & 0 & 1 & 0 & 0 \\
\hline Greece & 1 & 1 & 0 & 0 & 0 & 1 & 0 & 0 \\
\hline Grenada & 0 & 0 & 0 & 0 & 0 & 0 & 1 & 0 \\
\hline Guatemala & 1 & 1 & 0 & 0 & 0 & 0 & 1 & 0 \\
\hline Guinea-Bissau & 0 & 0 & 1 & 0 & 0 & 0 & 0 & 0 \\
\hline Guyana & 1 & 3 & 0 & 0 & 0 & 0 & 0 & 1 \\
\hline Honduras & 0 & 0 & 0 & 0 & 0 & 0 & 0 & 1 \\
\hline Hungary & 1 & 2 & 0 & 0 & 0 & 1 & 0 & 0 \\
\hline Iceland & 0 & 0 & 0 & 0 & 0 & 1 & 0 & 0 \\
\hline India & 1 & 2 & 0 & 1 & 0 & 0 & 0 & 0 \\
\hline Iran, Islamic Rep. & 1 & 2 & 0 & 1 & 0 & 0 & 0 & 0 \\
\hline Ireland & 0 & 0 & 0 & 0 & 0 & 1 & 0 & 0 \\
\hline Jamaica & 0 & 0 & 0 & 0 & 0 & 0 & 1 & 0 \\
\hline Japan & 0 & 0 & 0 & 1 & 0 & 0 & 0 & 0 \\
\hline Kazakhstan & 1 & 2 & 0 & 1 & 0 & 0 & 0 & 0 \\
\hline Korea, Dem. Rep. & 1 & 2 & 0 & 1 & 0 & 0 & 0 & 0 \\
\hline Korea, Rep. & 1 & 3 & 0 & 1 & 0 & 0 & 0 & 0 \\
\hline
\end{tabular}




\begin{tabular}{|c|c|c|c|c|c|c|c|c|}
\hline \multirow[b]{2}{*}{ Country } & \multirow[b]{2}{*}{$\begin{array}{l}\text { Has CER } \\
\text { Provision }\end{array}$} & \multirow[b]{2}{*}{$\begin{array}{c}\text { Index } \\
0-7\end{array}$} & \multicolumn{6}{|c|}{ Continent } \\
\hline & & & Africa & Asia & Australia & Europe & $\begin{array}{c}\text { North } \\
\text { America }\end{array}$ & $\begin{array}{c}\text { South } \\
\text { America }\end{array}$ \\
\hline Lebanon & 0 & 0 & 0 & 0 & 0 & 1 & 0 & 0 \\
\hline Lesotho & 1 & 2 & 1 & 0 & 0 & 0 & 0 & 0 \\
\hline Liechtenstein & 0 & 0 & 0 & 0 & 0 & 1 & 0 & 0 \\
\hline Luxembourg & 0 & 0 & 0 & 0 & 0 & 1 & 0 & 0 \\
\hline Madagascar & 1 & 2 & 1 & 0 & 0 & 0 & 0 & 0 \\
\hline Malawi & 1 & 2 & 1 & 0 & 0 & 0 & 0 & 0 \\
\hline Mali & 1 & 3 & 1 & 0 & 0 & 0 & 0 & 0 \\
\hline Malta & 1 & 1 & 0 & 0 & 0 & 1 & 0 & 0 \\
\hline Mauritius & 0 & 0 & 1 & 0 & 0 & 0 & 0 & 0 \\
\hline Mexico & 0 & 0 & 0 & 0 & 0 & 0 & 1 & 0 \\
\hline Monaco & 0 & 0 & 0 & 0 & 0 & 1 & 0 & 0 \\
\hline Mongolia & 1 & 3 & 0 & 1 & 0 & 0 & 0 & 0 \\
\hline Morocco & 0 & 0 & 1 & 0 & 0 & 0 & 0 & 0 \\
\hline Namibia & 1 & 2 & 1 & 0 & 0 & 0 & 0 & 0 \\
\hline New Zealand & 0 & 0 & 0 & 0 & 1 & 0 & 0 & 0 \\
\hline Niger & 1 & 4 & 1 & 0 & 0 & 0 & 0 & 0 \\
\hline Nigeria & 1 & 1 & 1 & 0 & 0 & 0 & 0 & 0 \\
\hline Norway & 1 & 3 & 0 & 0 & 0 & 1 & 0 & 0 \\
\hline Paraguay & 1 & 1 & 0 & 0 & 0 & 0 & 0 & 1 \\
\hline Peru & 1 & 4 & 0 & 0 & 0 & 0 & 0 & 1 \\
\hline Philippines & 0 & 0 & 0 & 1 & 0 & 0 & 0 & 0 \\
\hline Poland & 1 & 4 & 0 & 0 & 0 & 1 & 0 & 0 \\
\hline Portugal & 1 & 3 & 0 & 0 & 0 & 1 & 0 & 0 \\
\hline Russian Federation & 1 & 3 & 0 & 1 & 0 & 0 & 0 & 0 \\
\hline San Marino & 1 & 1 & 0 & 0 & 0 & 1 & 0 & 0 \\
\hline Seychelles & 1 & 3 & 1 & 0 & 0 & 0 & 0 & 0 \\
\hline Slovak Republic & 1 & 4 & 0 & 0 & 0 & 1 & 0 & 0 \\
\hline Solomon Islands & 0 & 0 & 0 & 0 & 1 & 0 & 0 & 0 \\
\hline South Africa & 1 & 3 & 1 & 0 & 0 & 0 & 0 & 0 \\
\hline Spain & 1 & 3 & 0 & 0 & 0 & 1 & 0 & 0 \\
\hline Sri Lanka & 1 & 1 & 0 & 1 & 0 & 0 & 0 & 0 \\
\hline St. Vincent and the Grenadines & 0 & 0 & 0 & 0 & 0 & 0 & 1 & $\mathrm{C}$ \\
\hline Suriname & 1 & 1 & 0 & 0 & 0 & 0 & 0 & 1 \\
\hline Sweden & 1 & 1 & 0 & 0 & 0 & 1 & 0 & $\mathrm{C}$ \\
\hline Syrian Arab Republic & 0 & 0 & 0 & 1 & 0 & 0 & 0 & $\mathrm{C}$ \\
\hline Tajikistan & 1 & 2 & 0 & 1 & 0 & 0 & 0 & $\mathrm{C}$ \\
\hline Tanzania & 0 & 0 & 1 & 0 & 0 & 0 & 0 & $\mathrm{c}$ \\
\hline Togo & 1 & 2 & 1 & 0 & 0 & 0 & 0 & $\mathrm{C}$ \\
\hline Trinidad and Tobago & 0 & 0 & 0 & 0 & 0 & 0 & 1 & $\mathrm{c}$ \\
\hline Tunisia & 0 & 0 & 1 & 0 & 0 & 0 & 0 & $\mathrm{c}$ \\
\hline Ukraine & 1 & 2 & 0 & 0 & 0 & 1 & 0 & 0 \\
\hline United Kingdom & 0 & 0 & 0 & 0 & 0 & 1 & 0 & $\mathrm{C}$ \\
\hline United States & 0 & 0 & 0 & 0 & 0 & 0 & 1 & $\mathrm{c}$ \\
\hline Uzbekistan & 1 & 2 & 0 & 1 & 0 & 0 & 0 & $\mathrm{c}$ \\
\hline Venezuela, RB & 1 & 3 & 0 & 0 & 0 & 0 & 0 & 1 \\
\hline Vietnam & 1 & 1 & 0 & 1 & 0 & 0 & 0 & 0 \\
\hline Yemen, Rep. & 0 & 0 & 0 & 1 & 0 & 0 & 0 & 0 \\
\hline Zambia & 1 & 3 & 1 & 0 & 0 & 0 & 0 & 0 \\
\hline Zimbabwe & 0 & 0 & 1 & 0 & 0 & 0 & 0 & 0 \\
\hline
\end{tabular}




\title{
Appendix 3 - Supporting Figures and Tables for the Empirical Analysis Including Countries with CER's up to 2010
}

\begin{abstract}
A Brief Note
Due to the way EPI is constructed, we had to date all control variables to 1999 and only use only those countries with CER's up until that time. We did this to avoid/mitigate possible measurement error. In the specifications presented here in Appendix 3, we also included those countries that added CER's from 1999-2010 (the last year of the 2012 EPI data range). The results, which likely also contain some measurement error, are reported below and confirm our primary results.
\end{abstract}


Table A3.1 - Descriptive Statistics for the Dependent, Control, and Instrumental Variables

\begin{tabular}{|c|c|c|c|c|c|}
\hline & \multicolumn{5}{|c|}{ Summary Statistics } \\
\hline & Observations & Mean & Standard Deviation & Minimum & Maximum \\
\hline \multicolumn{6}{|l|}{ Dependent Variables } \\
\hline Environmental Performance Index & 103 & 54.30 & 10.10 & 25.32 & 76.69 \\
\hline Ecosystem Vitality & 103 & 49.17 & 11.57 & 17.09 & 69.61 \\
\hline Environmental Health & 125 & 60.50 & 28.61 & 12.31 & 100.00 \\
\hline \multicolumn{6}{|l|}{ Primary Independent Variables } \\
\hline Has CER Provision & 134 & 0.679 & 0.469 & 0 & 1 \\
\hline Index 0-7 & 134 & 1.612 & 1.381 & 0 & 5 \\
\hline \multicolumn{6}{|l|}{ Control Variables } \\
\hline In GDP/Capita & 125 & 8.529 & 1.258 & 5.71 & 10.95 \\
\hline In GDP/Capita Squared & 125 & 74.31 & 21.330 & 32.62 & 119.96 \\
\hline Party to ICESCR & 134 & 0.970 & 0.171 & 0 & 1 \\
\hline Rule of Law & 134 & 0.490 & 0.212 & 0.059 & 0.894 \\
\hline In Pop. Density & 133 & 4.062 & 1.456 & 0.425 & 9.674 \\
\hline Africa & 134 & 0.291 & 0.456 & 0 & 1 \\
\hline North America & 134 & 0.112 & 0.316 & 0 & 1 \\
\hline South America & 134 & 0.097 & 0.297 & 0 & 1 \\
\hline Europe & 134 & 0.284 & 0.452 & 0 & 1 \\
\hline Australia & 134 & 0.022 & 0.148 & 0 & 1 \\
\hline Asia & 134 & 0.194 & 0.397 & 0 & 1 \\
\hline \multicolumn{6}{|l|}{ Instrumental Variables } \\
\hline ER Count Before & 134 & 38.20 & 38.79 & 0 & 117 \\
\hline Count of Other ESR & 134 & 3.91 & 2.32 & 0 & 8 \\
\hline Constitution/Provision Age & 134 & 24.86 & 30.34 & 1 & 223 \\
\hline
\end{tabular}


Table A3.2 - Full Environmental Performance Index and Has/Doesn't Have CER

\begin{tabular}{|c|c|c|c|c|}
\hline & \multicolumn{4}{|c|}{ LHS Variable: Environmental Performance Index } \\
\hline & Model (1.A) & Model (1.B) & Model (2.A) & Model (2.B) \\
\hline \multirow[t]{2}{*}{ Has CER Provision } & $2.997^{*}$ & $7.396 * * *$ & 1.323 & $5.987^{* *}$ \\
\hline & $(1.540)$ & $(2.137)$ & $(1.905)$ & $(2.471)$ \\
\hline \multirow[t]{2}{*}{ In GDP/Capita } & $-15.39 * *$ & $-16.74 * *$ & $-18.07^{* *}$ & $-19.69 * * *$ \\
\hline & $(6.561)$ & $(6.424)$ & $(7.164)$ & $(7.110)$ \\
\hline \multirow[t]{2}{*}{ In GDP/Capita Sq. } & $1.038 * *$ & $1.131 * * *$ & $1.069 * *$ & $1.205^{* * *}$ \\
\hline & $(0.407)$ & $(0.399)$ & $(0.446)$ & $(0.442)$ \\
\hline \multirow[t]{2}{*}{ Party to ICESCR } & 7.711 & 9.651 & 7.889 & $10.81^{*}$ \\
\hline & $(6.567)$ & $(6.102)$ & $(5.402)$ & $(5.886)$ \\
\hline \multirow[t]{2}{*}{ Rule of Law (1998) } & $20.00 * *$ & $20.98 * * *$ & $21.69 * * *$ & $22.33^{* * *}$ \\
\hline & $(7.756)$ & $(7.653)$ & $(7.492)$ & $(7.507)$ \\
\hline \multirow[t]{2}{*}{ In Pop. Density } & 0.264 & 0.282 & 0.311 & 0.526 \\
\hline & $(0.546)$ & $(0.574)$ & $(0.598)$ & $(0.610)$ \\
\hline \multirow[t]{2}{*}{ Constant } & $87.21^{* * *}$ & $86.11^{* * *}$ & $102.7^{* * *}$ & $99.33^{* * *}$ \\
\hline & $(27.43)$ & $(27.13)$ & $(29.92)$ & $(30.94)$ \\
\hline Observations & 100 & 100 & 100 & 100 \\
\hline Geographic Controls & No & No & Yes & Yes \\
\hline R-squared & 0.503 & 0.466 & 0.593 & 0.555 \\
\hline Adjusted R-squared & 0.471 & 0.431 & 0.542 & 0.500 \\
\hline
\end{tabular}

Note(s): LHS variable: 2012 release. Controls: 1999. CERs and IVs: up to 2010. Models with ".B" notation are the second stage results from IV regression. Standard errors in parentheses

P-Value Notation: $* \mathrm{p}<0.10, * * \mathrm{p}<0.05, * * * \mathrm{p}<0.01$ 
Table A3.5 - Ecosystem Vitality Component/Objective and CER Index 0-7

\begin{tabular}{|c|c|c|c|c|}
\hline & \multicolumn{4}{|c|}{ LHS Variable: Ecosystem Vitality Component } \\
\hline & Model (7.A) & Model (7.B) & Model (8.A) & Model (8.B) \\
\hline \multirow[t]{2}{*}{ Index 0-7 } & $2.087^{* *}$ & $3.480 * * *$ & $1.461^{*}$ & $3.266 * *$ \\
\hline & $(0.797)$ & $(1.157)$ & $(0.771)$ & $(1.314)$ \\
\hline \multirow[t]{2}{*}{ In GDP/Capita } & $-33.35 * * *$ & $-32.48 * * *$ & $-32.73 * *$ & $-31.18 * *$ \\
\hline & $(10.20)$ & $(10.55)$ & $(13.12)$ & $(13.51)$ \\
\hline \multirow[t]{2}{*}{ In GDP/Capita Sq. } & $1.705^{* * *}$ & $1.638^{* *}$ & $1.607^{* *}$ & $1.538^{*}$ \\
\hline & $(0.626)$ & $(0.649)$ & $(0.779)$ & $(0.804)$ \\
\hline \multirow[t]{2}{*}{ Party to ICESCR } & 6.213 & 9.872 & 11.07 & $14.28 *$ \\
\hline & (7.219) & $(7.365)$ & $(6.981)$ & $(7.851)$ \\
\hline \multirow[t]{2}{*}{ Rule of Law (1998) } & $23.13^{* *}$ & $27.25 * *$ & $26.29 * * *$ & $28.38^{* * *}$ \\
\hline & $(10.66)$ & $(10.69)$ & $(9.942)$ & $(10.09)$ \\
\hline \multirow[t]{2}{*}{ In Pop. Density } & -0.429 & -0.182 & 0.341 & 0.760 \\
\hline & $(0.882)$ & $(0.872)$ & $(0.837)$ & $(0.794)$ \\
\hline \multirow[t]{2}{*}{ Constant } & $188.5^{* * *}$ & $176.8^{* * *}$ & $174.1^{* * *}$ & $157.2 * * *$ \\
\hline & (43.19) & $(44.34)$ & $(57.31)$ & $(58.77)$ \\
\hline Observations & 100 & 100 & 100 & 100 \\
\hline Geographic Controls & No & No & Yes & Yes \\
\hline R-squared & 0.205 & 0.175 & 0.382 & 0.342 \\
\hline Adjusted R-squared & 0.153 & 0.122 & 0.305 & 0.260 \\
\hline \multicolumn{5}{|c|}{ Note(s): LHS variable: 2012 release. Controls: 1999. CERs and IVs: up to 2010.} \\
\hline \multicolumn{5}{|c|}{ Models with ".B" notation are the second stage results from IV regression. } \\
\hline \multicolumn{5}{|c|}{ Standard errors in parentheses } \\
\hline \multicolumn{5}{|c|}{ P-Value Notation: $* \mathrm{p}<0.10, * * \mathrm{p}<0.05, * * * \mathrm{p}<0.01$} \\
\hline
\end{tabular}


Table A3.8 - Selected First-Stage Instrumental Variables Results and Test Statistics

\begin{tabular}{|c|c|c|c|c|c|c|c|c|c|c|c|c|}
\hline \multirow{3}{*}{$\begin{array}{l}\text { LHS Variable } \\
\text { Model Number }\end{array}$} & \multicolumn{12}{|c|}{ Selected Instrumental Variables Results } \\
\hline & \multicolumn{4}{|c|}{ Environmental Performance Index } & \multicolumn{4}{|c|}{ Ecosystem Viability Component } & \multicolumn{4}{|c|}{ Environmental Health Component } \\
\hline & 1.B & 2.B & 3.B & 4.B & 5.B & 6.B & 7.B & 8.B & 9.B & 10.B & 11.B & 12.B \\
\hline Instrumental Variables & \multicolumn{12}{|c|}{ P-Values } \\
\hline CER Count Before & 0.000 & 0.000 & 0.001 & 0.001 & 0.001 & 0.001 & 0.001 & 0.000 & 0.000 & 0.000 & 0.000 & 0.000 \\
\hline Count of Other ESR & 0.030 & 0.083 & 0.037 & 0.138 & 0.037 & 0.138 & 0.005 & 0.059 & 0.005 & 0.059 & 0.019 & 0.119 \\
\hline \multirow[t]{2}{*}{ Constitution/Provision Age } & 0.033 & 0.162 & 0.069 & 0.165 & 0.069 & 0.165 & 0.065 & 0.266 & 0.065 & 0.266 & 0.137 & 0.305 \\
\hline & \multicolumn{8}{|c|}{ Coefficient Signs } & \multirow[b]{2}{*}{+} & \multirow[b]{2}{*}{+} & \multirow[b]{2}{*}{+} & \\
\hline CER Count Before & + & + & + & + & + & + & + & + & & & & + \\
\hline Count of Other ESR & + & + & + & + & + & + & + & + & + & + & + & + \\
\hline Constitution/Provision Age & - & - & - & - & - & - & - & - & - & - & - & - \\
\hline Test Statistics & & & & & \multicolumn{4}{|c|}{ P-Values } & & & & \\
\hline Hansen's J-Statistic & 0.7874 & 0.5243 & 0.6803 & 0.4734 & 0.468 & 0.5161 & 0.5788 & 0.8508 & 0.5788 & 0.8508 & 0.596 & 0.8652 \\
\hline Robust F-Statistic & 0.000 & 0.000 & 0.000 & 0.000 & 0.000 & 0.000 & 0.000 & 0.000 & 0.000 & 0.000 & 0.000 & 0.000 \\
\hline $\begin{array}{l}\text { Note(s): The } p \text {-values for the } \\
\text { IV extension of the correspo } \\
\text { The null hypothesis for the }\end{array}$ & $\begin{array}{l}\text { strumen } \\
\text { ing "\#.A" } \\
\text { oust F-St }\end{array}$ & $\begin{array}{l}\text { al variak } \\
\text { model. T } \\
\text { tistic is } t\end{array}$ & $\begin{array}{l}\text { les are } \mathrm{fr} \\
\text { he null hy } \\
\text { that the ir }\end{array}$ & $\begin{array}{l}\text { rom the f } \\
\text { ypothesis } \\
\text { nstrumer }\end{array}$ & $\begin{array}{l}\text { r stage c } \\
\text { r Hanse } \\
\text { are wea }\end{array}$ & $\begin{array}{l}f \text { the IV } \\
\text { n's J-Sta }\end{array}$ & $\begin{array}{l}\text { egressio } \\
\text { stic is } t\end{array}$ & $\begin{array}{l}\text { s. Each } \\
\text { at all in }\end{array}$ & $\begin{array}{l}\text { odel nun } \\
\text { cruments }\end{array}$ & $\begin{array}{l}\text { ber abo } \\
\text { are valic }\end{array}$ & e is the & \\
\hline
\end{tabular}




\section{Appendix 4 - Supporting Tables for the Repeated Empirical Analysis Using the 2014 EPI Data}

\section{Notes on the $2014 \mathrm{EPI}$}

Compared to the $2012 \mathrm{EPI}$ - which ranked 132 countries on 22 performance indicators across ten categories - the 2014 EPI ranks 178 countries on 20 performance indicators across nine categories. The nine categories (and 20 performance indicators) are: health impacts (child mortality); air quality (household air quality and two measures of air pollution particulate matter exposure); water and sanitation (access to sanitation and drinking water); water resources (waste water treatment); agriculture (pesticide regulation and agricultural subsidies); forests (change in forest cover) fisheries (fish stocks and coastal shelf fishing pressure); biodiversity and habitat (critical habitat protection; marine protected areas; global biome protection; and national biome protection); and climate and energy (trends in carbon dioxide emissions per kilowatt-hour; change in trend of carbon intensity; and trend in carbon intensity). The first three categories (and six performance indicators) comprise the Environmental Health (EH) component of EPI, and the remaining six categories (and 13 performance indicators) comprise the Ecosystem Vitality (EV) component. Although the 2014 framework considers 20 indicators, access to electricity (the above "missing" twentieth indicator) is not included in the calculation of country scores.

Once the data for each component is collected and ready for inclusion in EPI, the authors again "weight" the data but do so in a manner different from the 2012 framework. On page 19 of the 2014 EPI Full Report and Analysis, it reads:

Each indicator is weighted within each issue category to create a single issue category score. These weightings are generally set according to the quality of the underlying dataset, as well as the relevance or fit of the indicator to assess the policy issue. If the underlying global data for a particular indicator is less reliable or relevant than others in the issue category, it will be weighted less heavily.

Continuing on page 20:

For example, the trends in carbon intensity indicators in the Climate and Energy category (Trend in Carbon Intensity and Change of Trend in Carbon Intensity) are weighted according to which indicator is more pertinent based on a country's economic development and policy obligations with respect to climate change mitigation. Policy issues are typically weighted roughly equally within their objective (e.g., Environmental Health and Ecosystem Vitality). However, contingent upon the strength of data in each category, slight adjustments to this weighting can be made. An important example in the $2014 \mathrm{EPI}$ is in the Ecosystem Vitality objective. Because both of the indicators in the Agriculture category are indirect measures of environmental performance (e.g., subsidies do not directly assess the environmental impacts of intensive agriculture practices), this category only comprises 5 percent of a country's score in the Ecosystem Vitality objective, as compared to 25 percent for the Climate and Energy category. 
To the extent that the 2012 EPI had clearly delineated weights for each indicator within the index, the weighting framework for the indicators within the 2014 index is not as obvious. Another change for 2014 is that now the EV and EH components are weighted "roughly (page 20)" equally in the composition of EPI, whereas in 2012 these components were respectively given weights of $70 \%$ and $30 \%$.

\section{Using the 2014 EPI Data}

The following results lend further support to our main empirical framework. Tables 1-8 replicate the main empirical specifications for the 2012 framework but use the 2014 data for $\mathrm{EPI}, \mathrm{EV}$, and EH. Tables 9-16 replicate the robustness specification presented in the paper for the 2012 framework but also use the 2014 data. The IV results again indicate that having a CER provision is positively related to environmental performance, and the same is true for the legal strength of CER provisions as measured by our CER index. In general, these results represent a robustness test for and demonstrate the soundness of our results and chosen empirical framework despite the myriad differences across the 2012 and $2014 \mathrm{EPI}$ data and calculations. 
Table A4.1 - Descriptive Statistics for the Dependent, Control, and Instrumental Variables

\begin{tabular}{|c|c|c|c|c|c|}
\hline & \multicolumn{5}{|c|}{ Summary Statistics } \\
\hline & Observations & Mean & Standard Deviation & Minimum & Maximum \\
\hline \multicolumn{6}{|l|}{ Dependent Variables } \\
\hline Environmental Performance Index & 91 & 53.31 & 16.89 & 18.43 & 83.29 \\
\hline Ecosystem Vitality & 91 & 42.89 & 16.13 & 5.82 & 77.31 \\
\hline Environmental Health & 91 & 68.93 & 22.65 & 27.42 & 99.44 \\
\hline \multicolumn{6}{|l|}{ Primary Independent Variables } \\
\hline Has CER Provision & 96 & 0.594 & 0.494 & 0 & 1 \\
\hline Index 0-7 & 96 & 1.385 & 1.372 & 0 & 4 \\
\hline \multicolumn{6}{|l|}{ Control Variables } \\
\hline In GDP/Capita & 89 & 8.683 & 1.237 & 6.22 & 10.95 \\
\hline In GDP/Capita Squared & 89 & 76.91 & 21.212 & 38.70 & 119.96 \\
\hline Party to ICESCR & 96 & 0.969 & 0.175 & 0 & 1 \\
\hline Rule of Law & 96 & 0.523 & 0.209 & 0.086 & 0.894 \\
\hline In Pop. Density & 95 & 4.021 & 1.577 & 0.425 & 9.674 \\
\hline Africa & 96 & 0.271 & 0.447 & 0 & 1 \\
\hline North America & 96 & 0.115 & 0.320 & 0 & 1 \\
\hline South America & 96 & 0.104 & 0.307 & 0 & 1 \\
\hline Europe & 96 & 0.292 & 0.457 & 0 & 1 \\
\hline Australia & 96 & 0.031 & 0.175 & 0 & 1 \\
\hline Asia & 96 & 0.188 & 0.392 & 0 & 1 \\
\hline \multicolumn{6}{|l|}{ Instrumental Variables } \\
\hline ER Count Before & 96 & 20.09 & 23.02 & 0 & 66 \\
\hline Count of Other ESR & 96 & 3.50 & 2.39 & 0 & 8 \\
\hline Constitution/Provision Age & 96 & 22.54 & 32.79 & 1 & 213 \\
\hline
\end{tabular}


Table A4.2 - Full Environmental Performance Index and Has/Doesn't Have CER

\begin{tabular}{|c|c|c|c|c|}
\hline & \multicolumn{4}{|c|}{ LHS Variable: Environmental Performance Index } \\
\hline & Model (1.A) & Model (1.B) & Model (2.A) & Model (2.B) \\
\hline \multirow[t]{2}{*}{ Has CER Provision } & $4.561^{* *}$ & $7.119 * * *$ & 2.417 & $5.478^{* *}$ \\
\hline & $(1.842)$ & $(2.334)$ & $(1.809)$ & $(2.516)$ \\
\hline \multirow[t]{2}{*}{ In GDP/Capita } & -5.910 & -6.110 & -0.458 & -2.060 \\
\hline & $(10.88)$ & $(11.00)$ & $(11.68)$ & $(11.49)$ \\
\hline \multirow[t]{2}{*}{ In GDP/Capita Sq. } & 0.961 & 0.999 & 0.563 & 0.704 \\
\hline & $(0.665)$ & $(0.673)$ & $(0.707)$ & $(0.696)$ \\
\hline \multirow[t]{2}{*}{ Party to ICESCR } & 2.238 & 1.724 & -1.773 & -2.387 \\
\hline & $(3.854)$ & $(4.373)$ & $(2.380)$ & $(3.261)$ \\
\hline \multirow[t]{2}{*}{ Rule of Law (1998) } & $14.94^{*}$ & $15.17^{* *}$ & $13.93^{*}$ & 12.30 \\
\hline & $(7.526)$ & $(7.543)$ & (7.579) & (7.772) \\
\hline \multirow[t]{2}{*}{ In Pop. Density } & 0.0698 & 0.280 & -0.256 & -0.0860 \\
\hline & $(0.570)$ & $(0.568)$ & $(0.533)$ & $(0.558)$ \\
\hline \multirow[t]{2}{*}{ Constant } & 17.49 & 14.31 & 7.546 & 9.383 \\
\hline & $(46.22)$ & $(46.74)$ & $(48.75)$ & $(48.23)$ \\
\hline Observations & 87 & 87 & 87 & 87 \\
\hline Geographic Controls & No & No & Yes & Yes \\
\hline R-squared & 0.811 & 0.806 & 0.850 & 0.844 \\
\hline Adjusted R-squared & 0.797 & 0.791 & 0.828 & 0.821 \\
\hline
\end{tabular}

Note(s): LHS variable: 2014 release. RHS variables as of 1999.

Models with ".B" notation are the second stage results from IV regression.

Standard errors in parentheses

P-Value Notation: ${ }^{*} p<0.10, * * p<0.05, * * * p<0.01$ 


\section{Table A4.5 - Ecosystem Vitality Component/Objective and CER Index 0-7}

\begin{tabular}{|c|c|c|c|c|}
\hline & \multicolumn{4}{|c|}{ LHS Variable: Ecosystem Vitality Component } \\
\hline & Model (7.A) & Model (7.B) & Model (8.A) & Model (8.B) \\
\hline \multirow[t]{2}{*}{ Index 0-7 } & 1.291 & $3.634 * * *$ & 0.755 & $3.118^{*}$ \\
\hline & $(0.940)$ & $(1.374)$ & $(0.911)$ & $(1.581)$ \\
\hline \multirow[t]{2}{*}{ In GDP/Capita } & $-37.00 * *$ & $-34.95^{* *}$ & $-25.99 *$ & $-24.60 *$ \\
\hline & $(15.59)$ & $(15.96)$ & $(14.82)$ & $(14.73)$ \\
\hline \multirow[t]{2}{*}{ In GDP/Capita Sq. } & $2.631 * * *$ & $2.546 * *$ & $1.959 * *$ & $1.921^{* *}$ \\
\hline & $(0.949)$ & $(0.978)$ & $(0.910)$ & $(0.909)$ \\
\hline \multirow[t]{2}{*}{ Party to ICESCR } & 0.436 & -1.345 & -4.037 & -4.800 \\
\hline & $(6.309)$ & $(5.840)$ & $(3.443)$ & $(4.104)$ \\
\hline \multirow[t]{2}{*}{ Rule of Law (1998) } & 9.381 & 10.69 & 7.062 & 5.979 \\
\hline & (9.900) & $(10.75)$ & $(10.57)$ & $(11.41)$ \\
\hline \multirow[t]{2}{*}{ In Pop. Density } & -0.446 & 0.0263 & -0.514 & -0.111 \\
\hline & $(0.813)$ & $(0.840)$ & $(0.779)$ & $(0.905)$ \\
\hline \multirow[t]{2}{*}{ Constant } & $156.1^{* *}$ & $140.9 * *$ & $117.4^{*}$ & $104.9 *$ \\
\hline & $(66.53)$ & $(68.15)$ & $(61.20)$ & (61.61) \\
\hline Observations & 87 & 87 & 87 & 87 \\
\hline Geographic Controls & No & No & Yes & Yes \\
\hline R-squared & 0.548 & 0.513 & 0.627 & 0.597 \\
\hline Adjusted R-squared & 0.515 & 0.476 & 0.573 & 0.538 \\
\hline
\end{tabular}

Note(s): LHS variable: 2014 release. RHS variables as of 1999.

Models with ".B" notation are the second stage results from IV regression.

Standard errors in parentheses

P-Value Notation: $* \mathrm{p}<0.10, * * \mathrm{p}<0.05, * * * \mathrm{p}<0.01$ 
Table A4.6 - Environmental Health Component/Objective and Has/Doesn't Have CER Index

\begin{tabular}{|c|c|c|c|c|}
\hline & \multicolumn{4}{|c|}{ LHS Variable: Environmental Health Component } \\
\hline & Model (9.A) & Model (9.B) & Model (10.A) & Model (10.B) \\
\hline \multirow[t]{2}{*}{ Has CER Provision } & 3.403 & 2.933 & 0.833 & 1.637 \\
\hline & $(2.105)$ & $(2.729)$ & $(2.008)$ & $(2.810)$ \\
\hline \multirow[t]{2}{*}{ In GDP/Capita } & $42.61 * * *$ & $40.82 * * *$ & $39.60 * * *$ & $33.37^{* *}$ \\
\hline & $(12.12)$ & $(12.30)$ & $(14.78)$ & $(14.10)$ \\
\hline \multirow[t]{2}{*}{ In GDP/Capita Sq. } & $-1.683 * *$ & $-1.520 * *$ & $-1.669 *$ & -1.277 \\
\hline & $(0.756)$ & $(0.763)$ & $(0.888)$ & $(0.853)$ \\
\hline \multirow[t]{2}{*}{ Party to ICESCR } & 6.300 & 4.739 & 2.044 & 1.607 \\
\hline & $(4.835)$ & $(5.071)$ & $(3.328)$ & $(3.297)$ \\
\hline \multirow[t]{2}{*}{ Rule of Law (1998) } & $24.11^{* *}$ & $17.48^{*}$ & $25.41 * *$ & $21.49 * *$ \\
\hline & $(11.35)$ & (9.929) & $(10.57)$ & $(9.933)$ \\
\hline \multirow[t]{2}{*}{ In Pop. Density } & 0.879 & 0.640 & 0.0199 & -0.168 \\
\hline & $(0.690)$ & $(0.638)$ & $(0.661)$ & $(0.635)$ \\
\hline \multirow[t]{2}{*}{ Constant } & $-195.7 * * *$ & $-186.5^{* * *}$ & $-160.7^{* *}$ & $-133.9 * *$ \\
\hline & $(49.88)$ & $(50.06)$ & $(63.02)$ & $(59.69)$ \\
\hline Observations & 87 & 87 & 87 & 87 \\
\hline Geographic Controls & No & No & Yes & Yes \\
\hline R-squared & 0.857 & 0.856 & 0.886 & 0.885 \\
\hline Adjusted R-squared & 0.847 & 0.845 & 0.869 & 0.868 \\
\hline \multicolumn{5}{|c|}{ Note(s): LHS variable: 2014 release. RHS variables as of 1999.} \\
\hline \multirow{2}{*}{\multicolumn{5}{|c|}{$\begin{array}{l}\text { Models with ".B" notation are the second stage results from IV regression. } \\
\text { Standard errors in parentheses }\end{array}$}} \\
\hline & & & & \\
\hline \multicolumn{5}{|c|}{ P-Value Notation: $* \mathrm{p}<0.10, * * \mathrm{p}<0.05, * * * \mathrm{p}<0.01$} \\
\hline
\end{tabular}


Table A4.8 - Selected First-Stage Instrumental Variables Results and Test Statistics

\begin{tabular}{|c|c|c|c|c|c|c|c|c|c|c|c|c|}
\hline \multirow{3}{*}{$\begin{array}{l}\text { LHS Variable } \\
\text { Model Number }\end{array}$} & \multicolumn{12}{|c|}{ Selected Instrumental Variables Results } \\
\hline & \multicolumn{4}{|c|}{ Environmental Performance Index } & \multicolumn{4}{|c|}{ Ecosystem Viability Component } & \multicolumn{4}{|c|}{ Environmental Health Component } \\
\hline & 1.B & 2.B & 3.B & 4.B & 5.B & 6.B & 7.B & 8.B & 9.B & 10.B & 11.B & 12.B \\
\hline Instrumental Variables & \multicolumn{12}{|c|}{ P-Values } \\
\hline CER Count Before & 0.000 & 0.000 & 0.000 & 0.000 & 0.000 & 0.000 & 0.000 & 0.000 & 0.000 & 0.000 & 0.000 & 0.000 \\
\hline Count of Other ESR & 0.000 & 0.004 & 0.000 & 0.001 & 0.000 & 0.004 & 0.000 & 0.001 & 0.000 & 0.004 & 0.000 & 0.001 \\
\hline \multirow[t]{2}{*}{ Constitution/Provision Age } & 0.064 & 0.213 & 0.037 & 0.125 & 0.064 & 0.213 & 0.037 & 0.125 & 0.064 & 0.213 & 0.037 & 0.125 \\
\hline & \multicolumn{12}{|c|}{ Coefficient Signs } \\
\hline CER Count Before & + & + & + & + & + & + & + & + & + & + & + & + \\
\hline Count of Other ESR & + & + & + & + & + & + & + & + & + & + & + & + \\
\hline Constitution/Provision Age & - & - & - & - & - & - & - & - & - & - & - & - \\
\hline Test Statistics & \multicolumn{12}{|c|}{ P-Values } \\
\hline Hansen's J-Statistic & 0.5866 & 0.5745 & 0.7349 & 0.6958 & 0.4465 & 0.4484 & 0.5595 & 0.6131 & 0.42 & 0.3883 & 0.4238 & 0.366 \\
\hline Robust F-Statistic & 0.000 & 0.000 & 0.000 & 0.000 & 0.000 & 0.000 & 0.000 & 0.000 & 0.000 & 0.000 & 0.000 & 0.000 \\
\hline
\end{tabular}


Table A4.9 - Descriptive Statistics for the Dependent, Control, and Instrumental Variables

\begin{tabular}{|c|c|c|c|c|c|}
\hline & \multicolumn{5}{|c|}{ Summary Statistics } \\
\hline & Observations & Mean & Standard Deviation & Minimum & Maximum \\
\hline \multicolumn{6}{|l|}{ Dependent Variables } \\
\hline Environmental Performance Index & 128 & 52.08 & 16.88 & 18.43 & 87.67 \\
\hline Ecosystem Vitality & 128 & 42.67 & 16.10 & 5.82 & 84.67 \\
\hline Environmental Health & 128 & 66.20 & 22.76 & 23.90 & 99.44 \\
\hline \multicolumn{6}{|l|}{ Primary Independent Variables } \\
\hline Has CER Provision & 134 & 0.679 & 0.469 & 0 & 1 \\
\hline Index 0-7 & 134 & 1.612 & 1.381 & 0 & 5 \\
\hline \multicolumn{6}{|l|}{ Control Variables } \\
\hline In GDP/Capita & 125 & 8.529 & 1.258 & 5.71 & 10.95 \\
\hline In GDP/Capita Squared & 125 & 74.31 & 21.330 & 32.62 & 119.96 \\
\hline Party to ICESCR & 134 & 0.970 & 0.171 & 0 & 1 \\
\hline Rule of Law & 134 & 0.490 & 0.212 & 0.059 & 0.894 \\
\hline In Pop. Density & 133 & 4.062 & 1.456 & 0.425 & 9.674 \\
\hline Africa & 134 & 0.291 & 0.456 & 0 & 1 \\
\hline North America & 134 & 0.112 & 0.316 & 0 & 1 \\
\hline South America & 134 & 0.097 & 0.297 & 0 & 1 \\
\hline Europe & 134 & 0.284 & 0.452 & 0 & 1 \\
\hline Australia & 134 & 0.022 & 0.148 & 0 & 1 \\
\hline Asia & 134 & 0.194 & 0.397 & 0 & 1 \\
\hline \multicolumn{6}{|l|}{ Instrumental Variables } \\
\hline ER Count Before & 134 & 38.20 & 38.79 & 0 & 117 \\
\hline Count of Other ESR & 134 & 3.91 & 2.32 & 0 & 8 \\
\hline Constitution/Provision Age & 134 & 24.86 & 30.34 & 1 & 223 \\
\hline
\end{tabular}


Table A4.10 - Full Environmental Performance Index and Has/Doesn't Have CER

\begin{tabular}{|c|c|c|c|c|}
\hline & \multicolumn{4}{|c|}{ LHS Variable: Environmental Performance Index } \\
\hline & Model (1.A) & Model (1.B) & Model (2.A) & Model (2.B) \\
\hline \multirow[t]{2}{*}{ Has CER Provision } & $4.451 * * *$ & $8.557^{* * *}$ & 2.240 & $6.998 * *$ \\
\hline & $(1.592)$ & $(2.369)$ & $(1.578)$ & $(2.678)$ \\
\hline \multirow[t]{2}{*}{ In GDP/Capita } & -4.883 & -7.354 & -2.674 & -5.639 \\
\hline & $(7.053)$ & $(7.438)$ & $(7.557)$ & $(8.068)$ \\
\hline \multirow[t]{2}{*}{ In GDP/Capita Sq. } & $0.878 * *$ & $1.054^{* *}$ & 0.633 & $0.874^{*}$ \\
\hline & $(0.441)$ & $(0.466)$ & $(0.469)$ & $(0.502)$ \\
\hline \multirow[t]{2}{*}{ Party to ICESCR } & 2.794 & 1.456 & -1.155 & -1.969 \\
\hline & $(3.436)$ & $(4.171)$ & $(2.082)$ & $(3.177)$ \\
\hline \multirow[t]{2}{*}{ Rule of Law (1998) } & $14.74 * *$ & $14.03 * *$ & $13.38 * *$ & 11.07 \\
\hline & $(6.507)$ & $(6.773)$ & $(6.276)$ & $(6.816)$ \\
\hline \multirow[t]{2}{*}{ In Pop. Density } & 0.175 & 0.414 & -0.313 & 0.0244 \\
\hline & $(0.520)$ & $(0.554)$ & $(0.488)$ & $(0.554)$ \\
\hline \multirow[t]{2}{*}{ Constant } & 14.84 & 20.75 & 21.99 & 26.90 \\
\hline & (29.67) & (31.13) & (31.46) & (33.98) \\
\hline Observations & 123 & 123 & 123 & 123 \\
\hline Geographic Controls & No & No & Yes & Yes \\
\hline R-squared & 0.796 & 0.784 & 0.829 & 0.816 \\
\hline Adjusted R-squared & 0.785 & 0.773 & 0.812 & 0.798 \\
\hline \multicolumn{5}{|c|}{ Note(s): LHS variable: 2014 release. Controls: 1999. CERs and IVs: up to 2010.} \\
\hline \multicolumn{5}{|c|}{ Models with ".B" notation are the second stage results from IV regression. } \\
\hline \multicolumn{5}{|c|}{ Standard errors in parentheses } \\
\hline \multicolumn{5}{|c|}{ P-Value Notation: ${ }^{*} \mathrm{p}<0.10, * * \mathrm{p}<0.05, * * * \mathrm{p}<0.01$} \\
\hline
\end{tabular}


Table A4.11 - Full Environmental Performance Index and CER Index 0-7

\begin{tabular}{|c|c|c|c|c|}
\hline & \multicolumn{4}{|c|}{ LHS Variable: Environmental Performance Index } \\
\hline & Model (3.A) & Model (3.B) & Model (4.A) & Model (4.B) \\
\hline \multirow[t]{2}{*}{ Index 0-7 } & $1.353^{* * *}$ & $3.250 * * *$ & $0.964 * *$ & $2.510 * * *$ \\
\hline & $(0.513)$ & $(0.856)$ & $(0.482)$ & $(0.941)$ \\
\hline \multirow[t]{2}{*}{ In GDP/Capita } & -4.177 & -6.305 & -2.157 & -3.471 \\
\hline & $(6.954)$ & (7.618) & (7.397) & (7.753) \\
\hline \multirow[t]{2}{*}{ In GDP/Capita Sq. } & $0.825^{*}$ & $0.971 * *$ & 0.597 & 0.716 \\
\hline & $(0.435)$ & $(0.476)$ & $(0.458)$ & $(0.480)$ \\
\hline \multirow[t]{2}{*}{ Party to ICESCR } & 3.525 & 2.595 & -1.032 & -1.356 \\
\hline & $(3.326)$ & $(4.147)$ & $(2.048)$ & $(2.963)$ \\
\hline \multirow[t]{2}{*}{ Rule of Law (1998) } & $15.81^{* *}$ & $17.09 * *$ & $14.04^{* *}$ & $13.43^{* *}$ \\
\hline & $(6.434)$ & $(6.661)$ & $(6.301)$ & $(6.636)$ \\
\hline \multirow[t]{2}{*}{ In Pop. Density } & 0.242 & 0.619 & -0.277 & -0.00132 \\
\hline & $(0.535)$ & $(0.584)$ & $(0.495)$ & $(0.559)$ \\
\hline \multirow[t]{2}{*}{ Constant } & 12.06 & 15.11 & 19.72 & 19.30 \\
\hline & $(29.38)$ & (31.98) & (31.08) & $(32.90)$ \\
\hline Observations & 123 & 123 & 123 & 123 \\
\hline Geographic Controls & No & No & Yes & Yes \\
\hline R-squared & 0.793 & 0.771 & 0.831 & 0.818 \\
\hline Adjusted R-squared & 0.782 & 0.759 & 0.814 & 0.800 \\
\hline \multicolumn{5}{|c|}{ Note(s): LHS variable: 2014 release. Controls: 1999. CERs and IVs: up to 2010.} \\
\hline \multicolumn{5}{|c|}{ Models with ".B" notation are the second stage results from IV regression. } \\
\hline \multicolumn{5}{|c|}{ Standard errors in parentheses } \\
\hline \multicolumn{5}{|c|}{ P-Value Notation: $* \mathrm{p}<0.10, * * \mathrm{p}<0.05, * * * \mathrm{p}<0.01$} \\
\hline
\end{tabular}


Table A4.13 - Ecosystem Vitality Component/Objective and CER Index 0-7

\begin{tabular}{|c|c|c|c|c|}
\hline & \multicolumn{4}{|c|}{ LHS Variable: Ecosystem Vitality Component } \\
\hline & Model (7.A) & Model (7.B) & Model (8.A) & Model (8.B) \\
\hline \multirow[t]{2}{*}{ Index 0-7 } & $1.705^{* *}$ & $5.022 * * *$ & $1.379 *$ & $4.662 * * *$ \\
\hline & $(0.745)$ & $(1.267)$ & $(0.746)$ & $(1.494)$ \\
\hline \multirow[t]{2}{*}{ In GDP/Capita } & $-30.25 * * *$ & $-32.17^{* *}$ & $-20.37^{*}$ & $-22.04 *$ \\
\hline & $(10.96)$ & $(12.88)$ & $(10.49)$ & $(12.55)$ \\
\hline \multirow[t]{2}{*}{ In GDP/Capita Sq. } & $2.190 * * *$ & $2.331^{* * *}$ & $1.534^{* *}$ & $1.694 * *$ \\
\hline & $(0.678)$ & $(0.798)$ & $(0.656)$ & $(0.779)$ \\
\hline \multirow[t]{2}{*}{ Party to ICESCR } & 1.400 & -0.758 & -2.971 & -3.998 \\
\hline & $(5.664)$ & $(5.753)$ & $(3.342)$ & $(4.526)$ \\
\hline \multirow[t]{2}{*}{ Rule of Law (1998) } & $14.99 *$ & $17.37^{*}$ & 12.11 & 11.99 \\
\hline & $(8.748)$ & $(10.17)$ & $(9.092)$ & $(10.45)$ \\
\hline \multirow[t]{2}{*}{ In Pop. Density } & -0.225 & 0.392 & -0.556 & -0.0191 \\
\hline & $(0.742)$ & $(0.831)$ & $(0.719)$ & $(0.846)$ \\
\hline \multirow[t]{2}{*}{ Constant } & $127.3^{* * *}$ & $126.3^{* *}$ & $97.64 * *$ & $94.39 *$ \\
\hline & $(46.47)$ & $(54.18)$ & $(43.73)$ & $(53.16)$ \\
\hline Observations & 123 & 123 & 123 & 123 \\
\hline Geographic Controls & No & No & Yes & Yes \\
\hline R-squared & 0.524 & 0.451 & 0.585 & 0.522 \\
\hline Adjusted R-squared & 0.500 & 0.423 & 0.543 & 0.475 \\
\hline \multicolumn{5}{|c|}{$\begin{array}{l}\text { Note(s): LHS variable: } 2014 \text { release. Controls: } 1999 . \text { CERs and IVs: up to } 2010 . \\
\text { Models with ".B" notation are the second stage results from IV regression. } \\
\text { Standard errors in parentheses }\end{array}$} \\
\hline \multicolumn{5}{|c|}{ P-Value Notation: ${ }^{*} p<0.10, * * p<0.05, * * * p<0.01$} \\
\hline
\end{tabular}


Table A4.14 - Environmental Health Component/Objective and Has/Doesn't Have CER Index

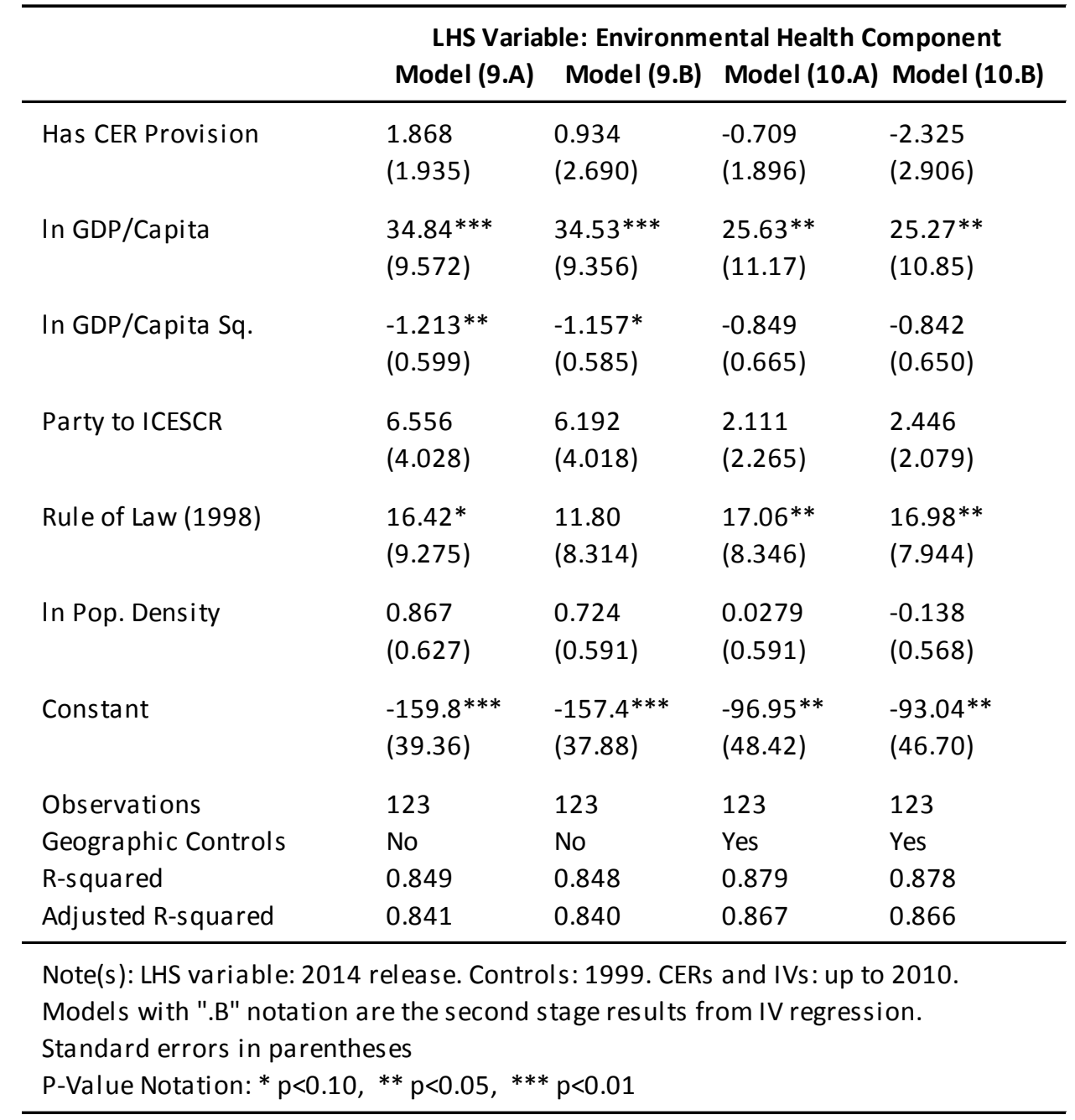

Table A4.15 - Environmental Health Component/Objective and CER Index 0-7 


\begin{tabular}{lllll}
\hline & \multicolumn{4}{c}{ LHS Variable: Environmental Health Component } \\
& Model (11.A) & Model (11.B) & Model (12.A) & Model (12.B) \\
\hline Index 0-7 & 0.825 & 0.387 & 0.341 & -0.856 \\
& $(0.678)$ & $(1.034)$ & $(0.639)$ & $(1.091)$ \\
In GDP/Capita & $34.94^{* * *}$ & $34.65^{* * *}$ & $25.17^{* *}$ & $24.63^{* *}$ \\
& $(9.328)$ & $(9.208)$ & $(11.11)$ & $(10.97)$ \\
In GDP/Capita Sq. & $-1.221^{* *}$ & $-1.167^{* *}$ & -0.808 & -0.795 \\
& $(0.586)$ & $(0.576)$ & $(0.662)$ & $(0.655)$ \\
Party to ICESCR & 6.704 & 6.253 & 1.867 & 2.285 \\
& $(4.127)$ & $(3.936)$ & $(2.510)$ & $(1.964)$ \\
Rule of Law (1998) & $17.03^{*}$ & 12.32 & $16.92^{* *}$ & $16.26^{* *}$ \\
& $(9.356)$ & $(8.480)$ & $(8.444)$ & $(8.100)$ \\
In Pop. Density & 0.942 & 0.756 & 0.142 & -0.151 \\
& $(0.644)$ & $(0.620)$ & $(0.605)$ & $(0.571)$ \\
Constant & $-160.8^{* * *}$ & $-158.1^{* * *}$ & $-97.15^{* *}$ & $-90.81^{*}$ \\
& $(38.27)$ & $(37.31)$ & $(48.20)$ & $(47.42)$ \\
Observations & 123 & 123 & 123 & 123 \\
Geographic Controls & No & No & Yes & Yes \\
R-squared & 0.850 & 0.849 & 0.879 & 0.875 \\
Adjusted R-squared & 0.842 & 0.841 & 0.867 & 0.863 \\
\hline
\end{tabular}

Note(s): LHS variable: 2014 release. Controls: 1999. CERs and IVs: up to 2010. Models with ".B" notation are the second stage results from IV regression.

Standard errors in parentheses

P-Value Notation: ${ }^{*} p<0.10,{ }^{* *} p<0.05,{ }^{* * *} p<0.01$ 
Table A4.16 - Selected First-Stage Instrumental Variables Results and Test Statistics

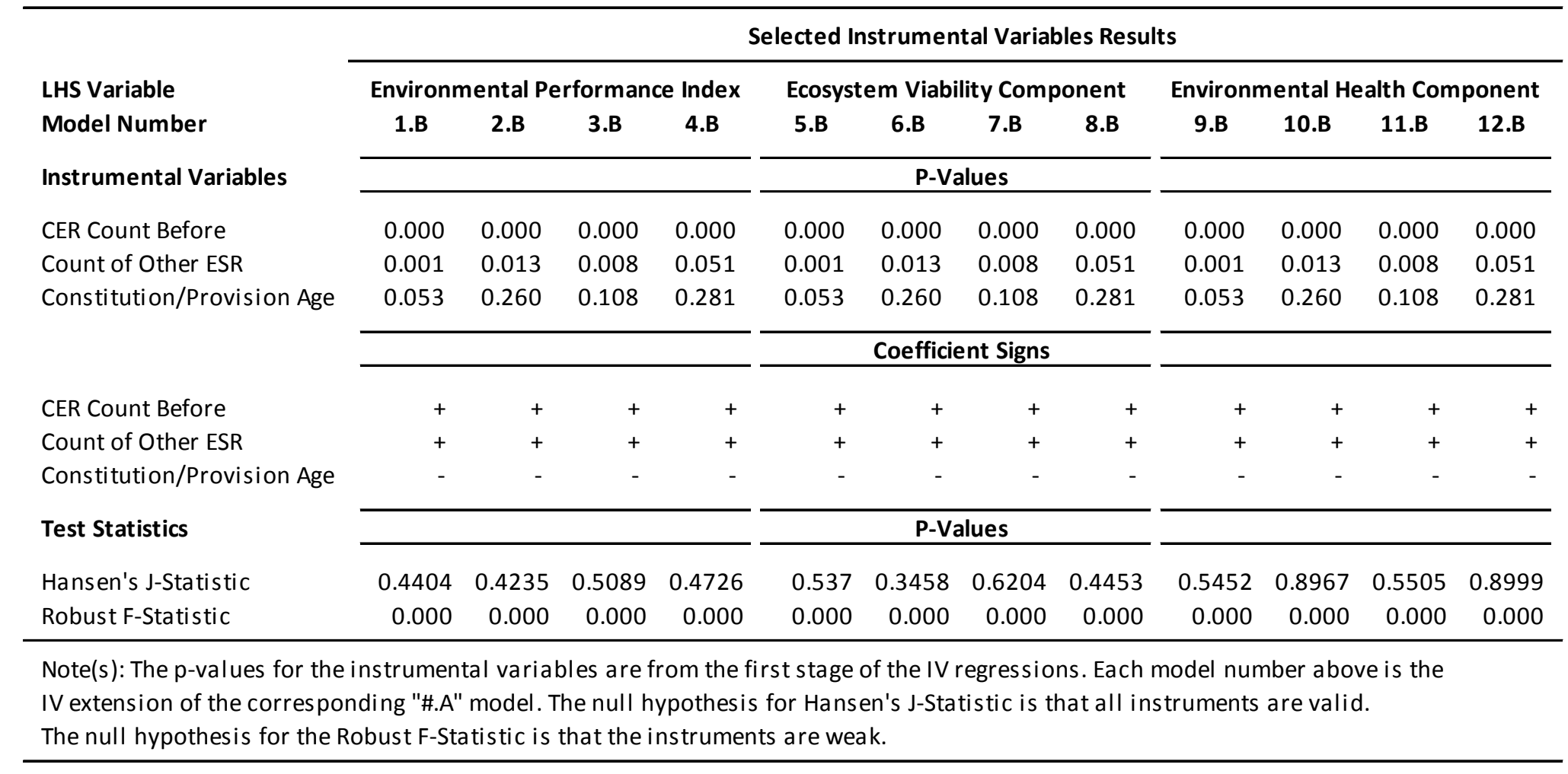

